\title{
AMICUS CURIAE SOBRE A SOLICITAÇÃO DE OPINIÃO CONSULTIVA \\ RELATIVA À FIGURA DO JUÍZO POLÍTICO OU IMPEACHMENT APRESENTADA PELA COMISSÃO INTERAMERICANA DE DIREITOS HUMANOS
}

\author{
AMICUS CURIAE ON THE REQUEST FOR AN ADVISORY OPINION \\ CONCERNING THE FIGURE OF THE POLITICAL JUDGMENT OR \\ IMPEACHMENT PRESENTED BY THE INTER-AMERICAN \\ COMMISSION ON HUMAN RIGHTS
}

Jorge Ernesto Roa Roa

Universidad Externado de Colombia (Bogotá, Colômbia)

Vera Karam de Chueiri et al.

Universidade Federal do Paraná - UFPR - (Curitiba, PR, Brasil)

Recebimento: 9 maio 2017

Aceitação: 11 maio 2017

\begin{abstract}
Como citar este trabalho / How to cite this work (informe a data atual de acesso / inform the current date of access):

ROA ROA, Jorge Ernesto; CHUEIRI, Vera Karam de et al. Amicus curiae sobre a solicitação de opinião consultiva relativa à figura do juízo político ou impeachment apresentada pela Comissão Interamericana de Direitos Humanos. Revista da Faculdade de Direito UFPR, Curitiba, PR, Brasil, v. 63, n. 1, p. 213-266, abr. 2018. ISSN $2236-7284$. Disponível em: <https://revistas.ufpr.br/direito/article/view/59379>. Acesso em: 30 abr. $2018 . \quad$ DOI: http://dx.doi.org/10.5380/rfdufpr.v63i1.59379.
\end{abstract}

\section{RESUMO}

O presente trabalho diz respeito à solicitação de Opinião Consultiva feita pela Comissão Interamericana de Direitos Humanos (CIDH) acerca dos julgamentos políticos e impeachment, de modo a fomentar e ampliar o debate sobre o tema. Nesse sentido, o Núcleo Constitucionalismo e Democracia, que integra o Centro de Estudos da Constituição (CCONS), do Programa de PósGraduação em Direito da Universidade Federal do Paraná (UFPR), e o Departamento de Direito Constitucional da Universidade Externado da Colômbia, ingressaram, em conjunto, como amicus curiae, e apresentaram esta opinião diante da Comissão Interamericana com o propósito de colaborar, teórica e praticamente, com o Sistema Interamericano de Direitos Humanos (SIDH). Na primeira parte do trabalho faz-se uma série de observações sobre a consulta formulada pela CIDH, inclusive quanto às próprias regras e estrutura do procedimento da função consultiva. Na segunda parte, faz-se referência ao papel e legitimidade dos tribunais internacionais e, concretamente, da Corte Interamericana de Direitos Humanos (Corte IDH), na proteção da democracia e dos direitos políticos. Na terceira parte, responde-se ao objeto central da consulta, sobre as garantias judiciais e a legalidade nos processos de impeachment e julgamentos políticos contra presidentes democraticamente eleitos. Finalmente, na quarta parte, alerta-se a Corte IDH sobre a importância de se especificar o alcance do artigo 23 da Convenção Americana de Direitos Humanos (CADH) em relação aos diferentes fenômenos que ocorrem nos Estados Partes da CADH. O objetivo do trabalho é oferecer à Corte IDH uma visão completa do conteúdo e de problemas concretos que surgem da solicitação de uma opinião 
consultiva tal como essa, formulada pela CIDH, como também um pronunciamento sobre o contexto jurídico e fático que rodeia este procedimento.

\title{
PALAVRAS-CHAVE
}

Opinião Consultiva. Julgamentos políticos e impeachment. Comissão Interamericana de Direitos Humanos (CIDH). Amicus curiae.

\begin{abstract}
This work concerns the request for an Advisory Opinion made by the Inter-American Commission on Human Rights (IACHR) on political judgments and impeachment, in order to encourage and broaden the debate on the subject. In this sense, the Núcleo Constitucionalismo e Democracia (Constitutionalism and Democracy Nucleus), which integrates the Centro de Estudos da Constituição (Center for Constitutional Studies - CCONS) of the Federal University of Paraná (UFPR) Law's LL.M and Ph.D Program, and the Constitutional Law Department of the Externado University of Colombia, have joined together as amicus curiae and presented their view before the Inter-American Commission, aiming to collaborate, theoretically and practically, with the Inter-American System of Human Rights (IASHR). The first part of this report presents comments on the consultation formulated by the IACHR, including the rules and structure of the advisory procedure itself. The second part deals with the role and legitimacy of international courts and tribunals - specifically, the Inter-American Court of Human Rights (IACHR) - for the protection of democracy and political rights. The third part refers to the core object of the consultation - on judicial guarantees and legality in impeachment proceedings and political trials against democratically elected presidents. Finally, in the fourth part, the Inter-American Court is warned about the importance of specifying the scope of Article 23 of the American Convention on Human Rights (ACHR) in relation to the different phenomena occurring in the States that have ratified it. The objective of this work is to provide the Inter-American Court with a complete view of the content and concrete problems that arise from the request for an advisory opinion such as that formulated by the IACHR, as well as with a statement on the legal and factual context surrounding this procedure.
\end{abstract}

\section{KEYWORDS}

Advisory Opinion. Political judgments and impeachment. Inter-American Commission on Human Rights (IACHR). Amicus curiae. 
Bogotá D.C. (Colômbia) e Curitiba (Brasil), 20 de março de 2018

\section{Senhoras e Senhores}

\section{Corte Interamericana de Direitos Humanos}

San José (Costa Rica)

Ref. Amicus curiae sobre a solicitação de opinião consultiva relativa à figura do juízo político ou impeachment apresentada pela Comissão Interamericana de Direitos Humanos.

Jorge Ernesto Roa Roa (docente e pesquisador do Departamento de Direito Constitucional da Universidade Externado da Colômbia), Vera Karam de Chueiri e demais pesquisadores do Núcleo de Constitucionalismo e Democracia/CCONS da Universidade Federal do Paraná apresentamos diante da honorável Corte Interamericana de Direitos Humanos (doravante Corte IDH) estas observações como amicus curiae (doravante $\mathrm{AC}$ ) em face da opinião consultiva (doravante OC) relativa à figura do juízo político ou impeachment apresentada pela Comissão Interamericana de Direitos Humanos (doravante Comissão ou CIDH).

A estrutura deste escrito de AC é a seguinte. Na primeira parte se apresentará uma série de observações sobre a consulta formulada pela CIDH, inclusive quanto às próprias regras e estrutura do procedimento da função consultiva da Corte IDH. Na segunda parte se fará referência ao papel e legitimidade dos tribunais internacionais e, concretamente, da Corte IDH, na proteção da democracia e dos direitos políticos. Na terceira parte se responderá ao objeto central da OC sobre as garantias judiciais e a legalidade nos processos de impeachment e julgamentos políticos contra presidentes democraticamente eleitos. Finalmente, na quarta parte, a Corte IDH será alertada sobre a importância de se especificar o alcance do artigo 23 da Convenção Americana de Direitos Humanos (doravante CADH) em relação aos diferentes fenômenos que ocorrem nos Estados Partes da CADH.

Como se pode inferir, o objetivo deste escrito é oferecer à Corte IDH uma visão completa, tanto do conteúdo quanto de problemas concretos que surgem da solicitação de OC formulada pela CIDH, como também um pronunciamento sobre o contexto jurídico e fático que rodeia este procedimento de OC. Dada a participação coletiva na elaboração deste escrito de AC, algumas partes foram originalmente escritas em castelhano e outras em português ${ }^{1}$.

\footnotetext{
${ }^{1}$ Este texto de AC é o produto da reflexão, deliberação e trabalho coletivo de todas as autoras e todos os autores que o subscrevem. No entanto, as partes 1, 2 e 4 podem ser atribuídas a Jorge Ernesto Roa Roa, e a parte 3, a Ananda Hadah Rodrigues Puchta, André Carias de Araújo, Caroline Godoi de Castro Oliveira, Estefânia Maria de Queiroz Barboza, Guilherme Ozório Santander Francisco, Heloisa Fernandes Câmara, José Arthur Castillo de Macedo, Kamila Maria Strapasson, Leonardo Cabral, Lucas Carli Cavassin, Luiz Henrique Krassuski Fortes, Marina Bonatto, Melina Girardi Fachin, Miguel Gualano de Godoy, Rafael Soares Leite, Rodrigo Kanayama e Vera Karam de Chueiri.
} 


\section{OS PROBLEMAS DA SOLICITAÇÃO DE OC FORMULADA PELA CIDH DESDE A ESTRUTURA DO PROCEDIMENTO CONSULTIVO PERANTE A CORTE IDH}

O objetivo desta primeira parte do AC é demostrar que, com base nas próprias regras estabelecidas pela Corte IDH sobre o procedimento consultivo, a presente solicitação de OC formulada pela CIDH não deveria ser admitida. De maneira subsidiária, será demonstrado que a Corte IDH deve se pronunciar sobre cada um dos aspectos abaixo indicados para dizer se: i) a regra que orientou o procedimento consultivo mudou; ii) as razões pelas quais uma regra sobre o procedimento consultivo não é aplicável a este caso ou iii) os argumentos para os quais considera que o presente pedido de uma OC não viola nenhuma regra estabelecida pela Corte Interamericana em relação ao seu próprio procedimento consultivo.

É importante ressaltar que nenhuma das observações feitas abaixo pretende negar os poderes da Corte IDH para definir os extremos tanto de sua própria competência contenciosa como de sua competência consultiva ${ }^{2}$. No entanto, este AC sustenta que é necessário que o Tribunal preserve a coerência das regras que estabeleceu para determinar a procedência de outras consultas ou para explicitar as razões pelas quais uma determinada regra de competência muda ou introduz uma exceção. Trata-se de um ônus mínimo de coerência interna que afeta a segurança jurídica e o direito de acesso à justiça que deve ser garantido pela própria Corte Interamericana.

Especificamente, a solicitação de OC formulada pela CIDH colide com as regras estabelecidas pela própria Corte IDH em relação aos quatro aspectos seguintes: i) os limites da competência consultiva, ii) a existência de assuntos pendentes de decisão perante a CIDH, iii) as consultas que potencialmente encobrem elementos de um caso contencioso e iv) consultas que se referem a fatos ou práticas dos Estados. Na sequência, expõe-se o conteúdo de cada uma dessas regras e as razões pelas quais essa solicitação de OC está em conflito com os parâmetros formulados pela Corte IIDH. Ao final, v) coloca-se a possibilidade de que a Corte IDH reformule as perguntas incluídas pela CIDH e formule alguns esclarecimentos adicionais.

\subsection{A SOLICITAÇÃO DE OC FORMULADA PELA CIDH EM FACE DOS LIMITES DA FUNÇÃO CONSULTIVA: A POTENCIAL ALTERAÇÃO DO PROCEDIMENTO CONTENCIOSO}

Nas vinte e quatro opiniões consultivas emitidas até agora, a Corte IDH estabeleceu limites para sua própria competência consultiva. Com efeito, depois de considerar que o seu âmbito de competência consultiva tem uma amplitude sem precedentes no direito internacional, a Corte reconheceu que essa característica não implica ausência de limites no seu exercício ${ }^{3}$.

Um dos cinco limites gerais indica que, no exercício de sua função consultiva, a Corte IDH não pode enfraquecer ou alterar sua função jurisdicional. Essa limitação vem do reconhecimento de que, entre

\footnotetext{
${ }^{2}$ Corte IDH. Identidad de género, e igualdad y no discriminación a parejas del mismo sexo. Obligaciones estatales en relación con el cambio de nombre, la identidad de género, y los derechos derivados de un vínculo entre parejas del mismo sexo (interpretación y alcance de los artículos 1.1, 3, 7, 11.2, 13, 17, 18 y 24, en relación con el artículo 1 de la Convención Americana sobre Derechos Humanos). Opinión Consultiva OC-24/17 de 24 de noviembre de 2017. Serie A No. 24, párr. 15.

${ }^{3}$ Jorge Ernesto Roa Roa. La función consultiva de la Corte Interamericana de Derechos Humanos. Universidad Externado de Colombia, Bogotá, 2015, p. 68.
} 
as funções consultiva e contenciosa, pode haver oposição em alguns $\operatorname{casos}^{4}$, especialmente se se usa aquela para impedir o processamento de um caso contencioso ${ }^{5}$.

Essa regra observa uma racionalidade interna positiva, pois pretende que uma das competências ou funções do Tribunal Interamericano (função consultiva) não interfira, desnaturalize ou afete outra das suas competências ou funções (função contenciosa). No entanto, há casos de pedidos de opinião consultiva que inevitavelmente repercutirão sobre os casos que tramitam, tanto perante a CIDH como perante a Corte IDH, pela via contenciosa das petições individuais.

O que se disse acima significa que a separação absoluta entre o procedimento contencioso e os resultados de um pedido específico de opinião consultiva não é possível no âmbito da prática judicial concreta do Tribunal Interamericano. Assim se tem advertido os Estados em vários procedimentos de consulta, e assim ocorre - como será mostrado abaixo - nesta solicitação de opinião consultiva formulada pela $\mathrm{CIDH}$, conforme se depreende de algumas das regras estabelecidas pela própria Corte IDH sobre o procedimento consultivo.

Por exemplo, neste procedimento de consulta, a Corte IDH tem uma oportunidade inédita para apontar a maneira como se deve harmonizar a regra que estabelece que a função consultiva não deve interferir em processos contenciosos, com aquela outra regra, também formulada pela Corte IDH, segundo a qual "o simples fato de existirem petições perante a Comissão relacionadas com o assunto da consulta não é suficiente para que a Corte se abstenha de responder às questões submetidas à consulta" 6 .

Na solicitação de OC feita pela CIDH no presente caso, a Corte IDH deve indicar a maneira pela qual o Tribunal entende que uma OC, que compartilha ratione matéria uma identidade de objeto com uma ou mais petições individuais que tramitam na CIDH, não afetará o trâmite ou resultado dessa petição individual. De fato, é plausível que existam maneiras de estabelecer essa separação entre os dois procedimentos. No entanto, a Corte IDH tem o ônus de aprofundar essa distinção funcional e de efeitos, sem se limitar a indicar, como mencionado anteriormente, que a existência de petições individuais perante a CIDH não é um óbice à emissão de uma OC.

\subsection{A SOLICITAÇÃO DE OC FORMULADA PELA CIDH EM FACE DA EXISTÊNCIA DE CASOS PENDENTES DE DECISÃO PERANTE A CIDH}

Como se afirmou na seção anterior, um dos elementos relevantes que se apresenta com particular intensidade nesta solicitação de OC formulada pela CIDH é o risco de potencial afetação ou alteração do procedimento contencioso de algumas petições individuais que atualmente tramitam na CIDH. Desde já, tanto a Corte IDH como a CIDH possuem as informações pertinentes. Mais ainda, a própria CIDH revelou na consulta que o objeto da mesma pode ser "entendido como relacionado"7 a três petições individuais que tramitam perante esse órgão. A saber: Manuel Zelaya (Honduras), Fernando Lugo (Paraguai) e Dilma Rousseff (Brasil).

\footnotetext{
${ }^{4}$ Corte IDH. “Otros tratados” objeto de la función consultiva de la Corte (Art. 64 Convención Americana sobre Derechos Humanos). Opinión Consultiva OC-1/82 de 24 de septiembre de 1982. Serie A No. 1, párr. 23.

${ }^{5}$ Jorge Ernesto Roa Roa, La función consultiva, op. cit., p. 69.

${ }^{6}$ Corte IDH, Identidad de género, e igualdad y no discriminación a parejas del mismo sexo, op. cit., párr. 24.

${ }^{7}$ CIDH. Democracia y Derechos Humanos en Contextos de Juicios Políticos. Solicitud de Opinión Consultiva a la Corte Interamericana de Derechos Humanos, párr. 56.
} 
Além do acima exposto, a própria CIDH informou em seu pedido de OC que nenhum desses casos foi decidido por esse órgão, porque essas petições estão na etapa inicial do procedimento contencioso (admissibilidade e estudo).

A tese central da CIDH para demonstrar que uma potencial OC, nos termos solicitados por esse organismo, não afetará nenhuma das petições individuais mencionadas, baseia-se em dois argumentos. Em primeiro lugar, a CIDH insiste que a consulta não se refere à situação particular de um Estado, mas sim que é uma consulta geral. Ou seja, a CIDH sugere que a OC seja uma análise abstrata que dispense qualquer referência a fatos, práticas ou regras específicas dos Estados ${ }^{8}$. Em segundo lugar, a CIDH afirma que é legítimo que a Corte IDH se pronuncie, por meio da via consultiva, sobre um tema comum às petições individuais que tramitam neste organismo, porque o objeto da consulta é mais amplo do que o objeto das três petições individuais anteriormente mencionadas.

O primeiro argumento da CIDH não é sólido e carece de racionalidade suficiente para demonstrar que a OC não afetará nenhuma das petições individuais. De fato, uma análise abrangente da consulta escrita apresentada pela Comissão permite inferir que o objeto da mesma foi construído de uma forma que redireciona necessariamente para práticas específicas de alguns Estados (como se analisará mais para frente) e versa sobre hipóteses que coincidem perfeitamente com a base fática das petições individuais pendentes de admissão, processamento e decisão perante a CIDH. Para ilustrar esse ponto, os dois exemplos a seguir são suficientes. Na solicitação da OC, a CIDH formulou a seguinte hipótese:

[...] si en casos en que se somete a juicio político al presidente por imputación de responsabilidades de tipo político, sea en forma explícita o de manera encubierta o por causales distintas a las previstas en la Constitución, existiría una suerte de "golpe de estado" parlamentario, que resultaría anómalo e inválido en los regímenes políticos de tipo presidencial y presidencial "parlamentarizado".

À luz do primeiro argumento da CIDH (a consulta não é particular, mas sim geral), surge a seguinte questão: Como a Corte IDH pode resolver essa consulta e oferecer uma resposta jurídica e interpretativa à hipótese previamente mencionada sem afetar os processos pendentes de decisão perante a CIDH?

Mais para frente, na mesma carta de solicitação da OC, a CIDH argumentou sobre a importância da Corte IDH emitir uma OC sobre os diferentes temas consultados. Entre outras razões, para a CIDH:

[...] la presente solicitud permitirá a la Corte determinar si en una situación en que en el juicio político se conforma una mayoría parlamentaria (que suele representar dos tercios o de la mitad más uno de los votos) que aprueba la acusación y destitución del Presidente de la República, aduciendo formalmente la configuración de alguna de las causales de índole penal pero encubriendo motivos derivados del cuestionamiento a su gestión o desempeño político, se estaría instrumentando dicho instituto para ejercer una suerte de voto de censura o falta de confianza al máximo líder del gobierno, a pesar de haber sido elegido democráticamente por el pueblo y de que el Congreso carece de esta

\footnotetext{
${ }^{8}$ Este tipo de argumento foi refutado da seguinte maneira: “Aunque es cierto que en la opinión consultiva no se tienen en cuenta los aspectos fácticos concretos de los casos que están pendientes de decisión en la Comisión, no es cierto que la opinión consultiva y la interpretación de la Corte no afecten o interfieran en esos procedimientos. Es plausible pensar que tanto el Estado como el peticionario utilizarán y pretenderán hacer valer el criterio de la Corte ante la Comisión”. Jorge Ernesto Roa Roa, La función consultiva, op. cit., p. 75.

${ }^{9}$ CIDH, Democracia y Derechos Humanos en Contextos de Juicios Políticos, op. cit., párr. 22.
} 
competencia en un régimen político de tipo presidencial o presidencial "parlamentarizado", ya que en ellos el Presidente carece de responsabilidad política ante el parlamento ${ }^{10}$.

De fato, pode-se afirmar que esta hipótese coincide com algumas ou várias bases fáticas dos casos pendentes perante a CIDH. Além disso, não é verdade que a consulta tenha sido formulada pela CIDH com um nível de abstração suficiente para evitar um impacto direto da OC nas petições individuais. Pelo contrário, uma resposta da Corte IDH baseada nessas hipóteses muito específicas e delimitadas pode configurar uma espécie de pré-julgamento de uma ou mais dessas petições individuais. Se tudo isso é verdade, então, como foi advertido em outro lugar:

[...] la Corte debe ser cuidadosa [...] para evitar resolver por vía consultiva aspectos que son propios del procedimiento contencioso, especialmente, porque este brinda mayores garantías de defensa a los Estados que el procedimiento consultivo ${ }^{11}$.

O segundo argumento da CIDH sustenta que o objeto de uma consulta por meio de uma OC é mais amplo e geral do que uma petição individual. A partir desse elemento incontestável, a CIDH infere que a OC não afetará os processos de petição individual pendentes de decisão perante ela própria. No entanto, esta abordagem da CIDH não é digna de consideração porque, como a solicitação de uma OC é mais ampla do que o objeto das petições individuais, não se infere que a OC sobre a matéria não afetará o trâmite contencioso daquelas petições individuais. Pelo contrário, o argumento da CIDH sugere que a solicitação da OC contém todos os elementos discutidos nas petições individuais e outros elementos adicionais. Assim, é evidente que um pronunciamento da Corte IDH sobre o assunto afetaria diretamente o objeto debatido nesses casos contenciosos ${ }^{12}$.

Evidentemente, a resposta às objeções formuladas nesta seção poderia ser a de afirmar que todas OCs impactam de alguma forma em algum procedimento contencioso perante a CIDH. Precisamente, daí deriva a importância, pertinência e fundamento da função consultiva. Além disso, pode-se dizer que é preferível transferir a eficácia do Sistema Interamericano de Proteção dos Direitos Humanos (doravante denominado SIDH) dos mecanismos contenciosos para os mecanismos consultivos e promocionais. Essa seria uma abordagem que vale a pena, mas deve enfrentar o fato de que existe uma regra consolidada da Corte IDH que é pensada para evitar que as OC interfiram ou afetem o procedimento contencioso. Por essa razão, a Corte IDH tem uma oportunidade de rever o fundamento, a razoabilidade e a sustentabilidade dessa regra.

\subsection{O POTENCIAL ENCOBRIMENTO DE UM CASO CONTENCIOSO}

Se a Corte IDH considera que deve alterar a regra que impede que uma OC interfira no procedimento contencioso ou estabelece que, ao contrário do que foi dito anteriormente, isso não acontece neste caso, ela ainda deve decidir sobre outra contradição entre a solicitação da OC formulada pela CIDH e uma das regras da Corte IDH sobre sua competência consultiva.

\footnotetext{
${ }^{10}$ CIDH, Democracia y Derechos Humanos en Contextos de Juicios Políticos, op. cit., párr. 26.

11 Jorge Ernesto Roa Roa, La función consultiva, op. cit., p. 71.

12 "La conclusión hasta ahora es que la Corte puede emitir opiniones consultivas sobre materias que están pendientes de decisión en la Comisión, siempre y cuando la opinión consultiva no interfiera en la decisión de los casos que se encuentran ante la Comisión. Este criterio es de difícil aceptación, pues es previsible que los criterios que la Corte establezca en su opinión consultiva influyen en el trabajo de la Comisión y serán utilizados por los Estados o peticionarios para defender sus propias causas”. Jorge Ernesto Roa Roa, La función consultiva, op. cit., p. 72.
} 
De fato, para a Corte IDH, é claro que os casos contenciosos não podem ser apresentados por meio de pedidos de opinião consultiva e que qualquer consideração ou fato que gere a consulta escapa dessa competência da Corte $^{13}$. Na Opinião Consultiva 15 de 1997, sobre os relatórios da Comissão Interamericana, a Corte fixou uma regra adicional para as solicitações que poderiam ocultar um caso contencioso. A Corte observou que o próprio Tribunal deve ter um cuidado especial para evitar que a resposta a uma das perguntas feitas na solicitação de uma opinião consultiva resulte em uma solução encoberta para um caso contencioso ${ }^{14}$.

Com relação a essa regra do procedimento consultivo, a solicitação de OC apresenta as três dificuldades a seguir. Em primeiro lugar, a CIDH solicita expressamente à Corte IDH que:

[...] emita un pronunciamiento de carácter general y no asociado a casos concretos, sobre las implicaciones concretas que, a la luz de la Convención Americana sobre Derechos Humanos y otros instrumentos interamericanos aplicables, tanto desde una dimensión colectiva como individual, puede tener un juicio político contra un/una Presidente/a que ha sido elegido democráticamente en condiciones que provocan fuertes cuestionamientos sobre las salvaguardas del debido proceso ${ }^{15}$.

Sem embargo, a pergunta que surge é: Como é possível que a Corte IDH emita um pronunciamento geral, abstrato e desvinculado de casos concretos, quando o objeto da consulta se refere a situações vigentes, atuais e concretas que ocorrem em vários Estados da região?

Em segundo lugar, resulta razoável e inevitável pensar que esta solicitação de OC pode encobrir um caso contencioso porque, em seu escrito, a própria CIDH faz referência a medidas adotadas por este organismo (i.e., comunicados da imprensa, medidas cautelares, relatórios e visitas) em situações concretas que coincidam com o objeto principal da consulta ${ }^{16}$.

O terceiro problema tem sua origem na mesma lógica interna das normas formuladas pela Corte IDH em relação ao seu próprio procedimento consultivo. De fato, a Corte Interamericana deve indicar a maneira de harmonizar a regra que proíbe encobrir casos contenciosos ou práticas dos Estados na forma de consulta com a regra, também fixada pela Corte IDH, que afirma que a função consultiva "no debe, en principio, ejercerse mediante especulaciones abstractas, sin una previsible aplicación a situaciones concretas que justifiquen el interés de que se emita una opinión consultiva"17.

Com relação a esses três problemas, não é suficiente que a Corte IDH indique, como indicou na chamada para apresentar observações neste procedimento de OC, que:

Esta solicitud no se refiere a ningún caso concreto en particular, ya que como se recuerda la función consultiva se trata de una interpretación en abstracto solicitada por los Estados miembros u órganos de la OEA a la Corte Interamericana acerca de la Convención Americana sobre Derechos Humanos o de otros tratados concernientes a la protección de los derechos humanos en el continente ${ }^{18}$.

Sobre os três problemas mencionados, insiste-se, é necessário um pronunciamento mais elaborado por parte da Corte IDH. Na opinião deste AC, a maneira de superar este questionamento é a

\footnotetext{
13 Jorge Ernesto Roa Roa, La función consultiva, op. cit., p. 76.

${ }^{14}$ Jorge Ernesto Roa Roa, La función consultiva, op. cit., p. 76.

${ }^{15}$ CIDH, Democracia y Derechos Humanos en Contextos de Juicios Políticos, op. cit., párr. 10.

${ }^{16} \mathrm{CIDH}$, Democracia y Derechos Humanos en Contextos de Juicios Políticos, op. cit., párrs. 6, 8 y 9.

${ }^{17}$ Corte IDH, Identidad de género, e igualdad y no discriminación a parejas del mismo sexo, op. cit., párr. 20.

${ }^{18}$ Corte IDH. CP-40/17. 21 de noviembre de 2017.
} 
inadmissibilidade da consulta ou a modificação da regra que proscreve as consultas que podem afetar o procedimento contencioso ou repercutir sobre casos pendentes de decisão pela CIDH.

\subsection{A SOLICITAÇÃO DE OC FORMULADA PELA CIDH SE REFERE A FATOS, PRÁTICAS E NORMAS DOS ESTADOS}

A consulta formulada pela CIDH refere-se constantemente a situações consolidadas em vários Estados da região (i.e., Honduras) ${ }^{19}$. Da mesma forma, a consulta se refere às normas de vários Estados (Argentina ou Paraguai) sobre as quais a CIDH aproxima alguma valoração. Do mesmo modo, a CIDH fez referência a práticas concretas dos Estados sobre as quais a CIDH adotou medidas de urgência e avaliou negativamente as práticas dos Estados ${ }^{20}$.

Por exemplo, no parágrafo 24 da consulta, a CIDH fez referência às causas que permitem o impeachment na Argentina e no Paraguai. Para efeitos da consulta formulada pela CIDH, os ordenamentos jurídicos desses dois países são importantes porque contêm causas mais amplas para a procedência do impeachment, pois não exigem o cometimento de um crime, mas apenas o "mau

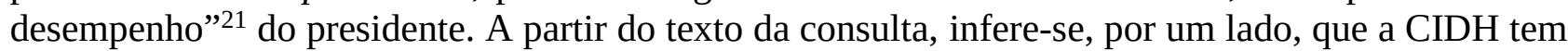
um critério negativo em relação a esses dois ordenamentos. Por outro lado, a consulta induz um pronunciamento da Corte IDH sobre essas duas normas internas dos Estados.

O primeiro problema é o reflexo de uma tensão que ocorre constantemente no procedimento consultivo quando o Estado ou órgão consultivo inclui, como considerações ilustrativas da consulta, medidas ou práticas internas de um ou vários Estados. Nesses casos, existe um problema de competência porque, como já foi apontado, a função consultiva não tem como objeto o estudo de fatos ou práticas, mas de disposições jurídicas.

O segundo problema é que essas referências concretas e diretas ao direito interno dos Estados, somadas ao conteúdo das perguntas formuladas pela CIDH, permitem inferir que é impossível responder à consulta sem que isso signifique uma análise de compatibilidade dessas normas internas com a CADH. Isto gera um problema de competência porque a legitimidade para solicitar que a Corte estude medidas internas corresponde somente aos Estados e de maneira alguma aos órgãos do Sistema Interamericano.

Sobre esse aspecto da consulta, a Corte IDH deve reiterar a consulta formulada pela CIDH, em conformidade com o artigo 64.1 da CADH. Isso significa que a Corte IDH não pode se pronunciar nesta OC sobre o direito interno dos Estados. Não só porque a CIDH não solicitou uma OC por meio do artigo 64.2 da CADH, mas porque essa possibilidade aparece reservada aos Estados.

\subsection{A CORTE IDH DEVE SE PRONUNCIAR SOBRE A POTENCIAL CONTRADIÇÃO ENTRE A SOLICITAÇÃO DE OC E AS REGRAS DO PROCEDIMENTO CONSULTIVO, AGIR PARA A REFORMULAÇÃO DAS PERGUNTAS DA CONSULTA E ESPECIFICAR OS EFEITOS DE SUA OC}

Como se indicou no início desta seção, a contradição entre a consulta feita pela Comissão e uma ou mais das regras mencionadas teria que levar à rejeição da solicitação de OC. Naturalmente, esta

\footnotetext{
${ }^{19}$ CIDH, Democracia y Derechos Humanos en Contextos de Juicios Políticos, op. cit., párr. 5.

${ }^{20}$ CIDH, Democracia y Derechos Humanos en Contextos de Juicios Políticos, op. cit., párrs. 8, 9 y 10.

${ }^{21} \mathrm{CIDH}$, Democracia y Derechos Humanos en Contextos de Juicios Políticos, op. cit., párr. 24.
} 
conclusão é estritamente jurídica e se baseia nas próprias regras estabelecidas pela Corte IDH em seu próprio procedimento consultivo. Isso significa que os argumentos desta seção não questionam a pertinência, importância e transcendência dos problemas jurídicos que contém a consulta formulada pela Comissão, mas a idoneidade da petição do ponto de vista dos parâmetros jurisprudenciais que orientam o processo consultivo.

Por essa razão, este escrito de AC propõe que o Tribunal se pronuncie expressamente sobre a potencial contradição entre o pedido de OC formulado pela CIDH e as regras mencionadas, de modo que se façam explícitas as razões pelas quais o Tribunal: i) considera que essa contradição é aparente ou inexistente; ii) indica a modificação de alguma dessas regras ou iii) justifica a introdução de uma exceção a essas regras para a consulta concreta.

Além disso, o Tribunal deve indicar quais são os aspectos jurídicos, fáticos e temporais que se alteraram entre o momento em que ele proferiu a resolução de 23 de junho de 2016, em que julgou inadmissível o pedido de OC feito em 19 de maio de 2016 pelo Secretário-Geral da Organização dos Estados Americanos (doravante OEA). Na citada resolução, a Corte IDH sustentou:

6. La Corte comprende la profunda preocupación del Secretario General, pero no puede menos que recordar su jurisprudencia en materia consultiva en lo atingente a la consulta de autos, a saber, que la petición de opinión consultiva: a) no debe encubrir un caso contencioso o pretender obtener prematuramente un pronunciamiento sobre un tema o asunto que podría eventualmente ser sometido a la Corte a través de un caso contencioso; b) no debe utilizarse como un mecanismo para obtener un pronunciamiento indirecto de un asunto en litigio o en controversia a nivel interno; c) no debe utilizarse como un instrumento de un debate político interno; d) no debe abarcar, en forma exclusiva, temas sobre los que la Corte ya se ha pronunciado en su jurisprudencia y e) no debe procurar la resolución de cuestiones de hecho, sino que busca desentrañar el sentido, propósito y razón de las normas internacionales sobre derechos humanos $y$, sobre todo, coadyuvar a los Estados miembros $y$ a los órganos de la OEA para que cumplan de manera cabal y efectiva sus obligaciones internacionales.

7. En vista de lo expuesto precedentemente, la Corte estima que, de emitir la opinión consultiva en autos, podría constituir un pronunciamiento prematuro sobre el tema o asunto en cuestión, el que le podría ser sometido posteriormente en el marco de un caso contencioso. Adicionalmente, considera que una respuesta a la consulta planteada podría implicar pronunciarse sobre un asunto que aún no ha sido resuelto a nivel interno. Así, la Corte también tiene presente que la solicitud de consulta bajo examen presenta una de aquellas situaciones en las cuales se desvirtuaría el propósito y contenido de la función consultiva con que ha sido investido este Tribunal por el artículo 64.1 de la Convención Americana $^{22}$. (grifo nosso)

Evidentemente, a solicitação de OC apresentada pelo Secretário-Geral da OEA em 2016 e a solicitação de OC apresentada pela CIDH em 2017 diferem em vários aspectos técnicos. No entanto, há elementos da resolução de inadmissibilidade - como os mencionados anteriormente - que são comuns a ambos os procedimentos e sobre os quais é importante que o Tribunal se manifeste.

Da mesma forma, sugere-se que o Tribunal faça uso de sua faculdade para alterar ou modificar as perguntas formuladas pela CIDH ou órgão consultor ${ }^{23}$, de forma que supere as colisões mencionadas entre a consulta feita pela CIDH e as regras da Corte IDH no procedimento consultivo.

\footnotetext{
${ }^{22}$ Corte IDH. Resolución de 23 de junio de 2016 sobre la solicitud de opinión consultiva presentada por el secretario general de la Organización de los Estados Americanos, párrs. 6 y 7.

${ }^{23}$ Jorge Ernesto Roa Roa, La función consultiva, op. cit., p. 79-81.
} 
Em todo caso, é importante que a Corte exerça essa faculdade de alterar as perguntas com algum respeito razoável ao objeto central da consulta. De fato, se é certo que a Corte IDH "no está necesariamente constreñida a los literales términos de las consultas que se le formulan," 24 também o é que a Corte IDH exige perguntas claras, concisas e precisas. Uma carga mínima relativa ao dever dos consultores de apresentar consultas precisas e concretas é que a Corte IDH observe a consulta como um marco que sua competência (consultiva) deve respeitar. Assim, uma coisa é que a Corte IDH possa estruturar livremente a maneira de dar uma resposta às consultas ${ }^{25} \mathrm{e}$, outra completamente diferente, que não existam limites materiais ou de conteúdo para a possibilidade de reformular as consultas com a finalidade de manter um esquema de congruência mínima entre o que foi consultado e aquilo que a Corte IDH responde.

Finalmente, se a Corte emite uma OC nesta consulta, o Tribunal não pode se limitar a reiterar, como tem feito desde a OC 21 até a OC 24, que as OCs são parâmetros de convencionalidade e vinculam todos os órgãos dos Estados, independentemente de serem parte do Poder Executivo, Legislativo ou Judiciário $^{26}$. É importante que o Tribunal indique exatamente o que essas autoridades de controle de convencionalidade devem fazer nesse tipo de caso. Somente assim, o Tribunal poderá contribuir para evitar a insegurança jurídica ou a ineficácia da interpretação feita pela Corte IDH em suas OC.

\section{A CORTE INTERAMERICANA FRENTE À PROTEÇÃO DA DEMOCRACIA E DOS DIREITOS POLÍTICOS: LEGITIMIDADE E ENFOQUES DE DEFERÊNCIA OU INTERFERÊNCIA}

O objetivo desta parte é fornecer alguns esclarecimentos sobre o conteúdo jurídico e político da consulta feita pela CIDH e sobre a necessidade de que a Corte IDH analise o grau de intervenção do Tribunal Interamericano em questões que não podem ser resolvidas unicamente pela interpretação do texto da CADH, pois têm fortes dimensões democráticas e políticas.

Com efeito, na opinião deste AC, a Corte IDH deve levar em conta que o conteúdo da consulta, embora verse sobre um aspecto que parece eminentemente jurídico (garantias judiciais e respeito aos direitos políticos em processos de impeachment), envolve uma potencial questão política de ordem complexa: i) o grau de controle dos parlamentos em relação ao presidente, ii) o grau de controle do judiciário sobre a ação dos parlamentos quando estes controlam o presidente, iii) o maior ou menor grau de dificuldade para remover do cargo um/a presidente/a eleito/a, iv) o grau de (hiper) presidencialismo dentro de uma democracia constitucional, v) a relação de i, ii e iii com respeito à vontade democrática expressa nas urnas no momento de eleger um/a presidente e vi) a relação entre i, ii e iii e o respeito aos direitos políticos de um/a presidente/a eleito/a.

Com relação aos seis aspectos acima indicados, a CIDH busca uma resposta consultiva da Corte IDH que tenha efeitos gerais e unificados para todos os Estados do SIDH. Os padrões estabelecidos nesta OC, além disso, farão parte do parâmetro de convencionalidade que deverá ser levado em consideração por todas as autoridades nacionais.

A tese central deste AC é que o conteúdo profundamente político da consulta não implica que a Corte IDH deva permanecer em silêncio sobre o assunto. No entanto, o Tribunal deve partir do reconhecimento de que, por um lado, i) é impossível oferecer uma opinião exclusivamente jurídica a

\footnotetext{
${ }^{24}$ Corte IDH, Identidad de género, e igualdad y no discriminación a parejas del mismo sexo, op. cit., párr. 25.

${ }^{25}$ Corte IDH, Identidad de género, e igualdad y no discriminación a parejas del mismo sexo, op. cit., párr. 52.

${ }^{26}$ Corte IDH, Identidad de género, e igualdad y no discriminación a parejas del mismo sexo, op. cit., párr. 26.
} 
questões que são inevitavelmente jurídicas e políticas. Por outro lado, ii) o Tribunal deve adotar um enfoque de deferência em virtude do alto conteúdo político da matéria consultada.

Em primeiro lugar, é importante observar que a combinação das duas medidas cautelares anteriormente mencionadas permitirá ao Tribunal Interamericano manter o equilíbrio político, democrático e jurídico interno do SIDH. Esse equilíbrio só é alcançado quando a Corte IDH amplia sua agenda a problemas diferentes ou novos, relacionados à proteção dos direitos humanos (tais como Direitos Econômicos, Sociais, Culturais e Ambientais - DESCA -, meio ambiente, políticas públicas, impeachments, etc.) e, ao mesmo tempo, assume enfoques de deferência com os Estados. Isso ocorre porque, nessas áreas, a intervenção judicial se centra na identificação de violações e déficits de proteção e no estabelecimento de um conjunto de parâmetros gerais para resolvê-los. No entanto, os Estados têm a obrigação de concretizar esses parâmetros e adotar medidas específicas para superar, não a violação dos direitos de uma pessoa ou grupo, mas a situação estrutural que deu origem a essa violação de direitos. Trata-se, em suma, de uma espécie de modelo bilateral de superação de situações estruturais ou políticas que causam a vulnerabilidade dos direitos humanos.

Em segundo lugar, este AC adverte que a deferência não implica um certo minimalismo judicial ou que a Corte IDH assuma a jurisprudência desenvolvida nos Estados Unidos sobre questões políticas. No entanto, é imprescindível que a Corte IDH identifique todas as arestas políticas e de direito internacional que envolvem os casos ou consultas que chegam a esse tribunal e amplie a agenda de proteção dos direitos humanos nas Américas. Só assim, o Tribunal pode dar uma resposta diferenciada quanto ao nível de intervenção da Corte e quanto ao grau de otimização do princípio de subsidiariedade no SIDH.

Em terceiro lugar, este AC enfatiza que o enfoque de deferência não é uma margem de apreciação nacional. Essa diferença sutil é importante do ponto de vista técnico. A deferência não está relacionada a uma posição supostamente melhor das autoridades internas, mas à matéria do caso ou consulta que se encontra sob o conhecimento da Corte IDH. Quando esse conteúdo envolve matérias sobre as quais a Corte Interamericana tem competência limitada ou quando se refere a um profundo desacordo social ou político dentro de um Estado, o qual deve ser resolvido através dos mecanismos de participação democrática estabelecidos em cada Estado, a Corte IDH deve assumir uma posição de deferência.

O propósito da intervenção judicial nesses casos deve ser o de promover a deliberação dentro dos Estados. Se a Corte CIDH puser fim a um profundo desacordo político em um Estado, isso não só enfraquece os direitos de participação política dos cidadãos desse Estado, mas afeta a própria legitimidade democrática do Tribunal Interamericano.

Em quarto lugar, em relação ao objeto específico desta consulta, a deferência implica reconhecer a existência de diferentes tradições constitucionais dentro da região. É claro que, embora haja um caminho comum latino-americano marcado pelo poder excessivo do presidente, cada uma dessas tradições constitucionais tem lidado de maneira diferente com o modo de configurar o procedimento de juízo político ou impeachment. A extensão das causas e procedimentos difere nos ordenamentos jurídicos de cada um dos países, conforme tem sido reconhecido pela CIDH na solicitação de OC. De forma que mal poderia a Corte IDH assinalar que, apesar dessas diferenças de configuração constitucional, a intervenção judicial interna nesses procedimentos deve ser a mesma em todos os países da região. 
Em quinto lugar, aqueles que subscrevem este AC consideram que é melhor transferir a eficácia - do SIDH - da função contenciosa para a função consultiva da Corte IDH. Contudo, a esse desejo compartilhado, opõe-se a existência de alguns casos em que o Tribunal Interamericano deve se pronunciar preferencialmente pela via contenciosa - se o caso for encaminhado pela CIDH - à via consultiva. Isto é, pelo fato de que a via contenciosa permite analisar as particularidades dos casos, da configuração normativa de cada Estado e do contexto que cercou a aplicação do julgamento político ou impeachment. A Corte Interamericana deve avaliar se, sobre o objeto desta consulta, é melhor emitir uma OC ou estabelecer padrões com base na análise concreta de assuntos contenciosos que se referem ao mesmo tema e já se encontram na agenda contenciosa do SIDH.

Em sexto lugar, em uma OC, a Corte IDH deve ser cuidadosa para evitar prejulgar, com raciocínios gerais, casos particulares e muito diferentes, tais como aqueles que têm ocorrido na região ao longo das últimas duas décadas em relação ao potencial uso desproporcionado dos juízos políticos e dos impeachments. Não se trata de evitar que se afete o procedimento contencioso, mas de prevenir uma resolução excessivamente vaga e indeterminada de algumas suposições que apresentam diferenças essenciais, as quais só podem ser analisadas quando aqueles são apresentados diretamente em seu contexto por meio da via contenciosa.

De fato, ao analisar os diferentes processos de remoção de um presidente eleito na região, a Corte IDH pode verificar que, em muitos casos, não se questiona a idoneidade da norma constitucional ou da norma legal interna dos juízos políticos ou impeachment. Essa pode ser perfeita do ponto de vista constitucional. O que se discute em vários desses casos é se os julgamentos políticos ou impeachments foram realizados sujeitos a essas regras legais ou constitucionais ou se se tratou de casos de não conformidade, uso desproporcional ou indevido de poder. Esta é uma razão adicional que justifica que a Corte IDH seja prudente para resolver as questões levantadas pela CIDH, de uma maneira geral, em uma OC quando por trás desses problemas existem, como foi mencionado anteriormente, casos diferentes de julgamentos políticos na região, que só podem ser totalmente apreciados pela via contenciosa.

Finalmente, a particularidade dos casos pode ajudar o Tribunal a distinguir e estabelecer critérios mais bem elaborados. Por haver petições individuais perante a CIDH sobre o mesmo tema, haverá uma oportunidade para que a Corte IDH se manifeste sobre a matéria e fixe os padrões em relação às garantias judiciais e os direitos políticos. Mesmo assim, não há urgência em emitir a OC pois não há na região um risco sério e iminente de utilização abusiva desses tipos de procedimentos internos de juízos políticos. Sobre a situação dos países em que isso aconteceu e gerou preocupação, como observou a CIDH, encontram-se em curso procedimentos contenciosos perante a CIDH que, de uma maneira ou de outra, chegarão à Corte IDH.

\section{AS GARANTIAS DO DEVIDO PROCESSO LEGAL E DA LEGALIDADE NOS JUÍZOS POLÍTICOS}

Como manifestado nas seções anteriores deste AC, está fora de dúvida a relevância e atualidade da preocupação da CIDH sobre os processos de impeachment contra chefes do Poder Executivo nos países que compõem o SIDH. O ponto central da OC diz respeito às garantias procedimentais previstas na $\mathrm{CADH}$ para que tais processos transcorram de modo a preservar o ambiente de legalidade democrática desenhado pelo SIDH.

Nesse sentido, na presente seção busca-se mostrar que, mesmo sem adentrar nas especificidades que envolvem as petições individuais pendentes de análise - os processos de impeachment envolvendo 
Honduras, Paraguai e Brasil -, ainda assim é possível que esta Corte dê maior concretude aos artigos $8^{\circ}, 9^{\circ}, 23$ e 25 da CADH na presente OC, colaborando para salvaguarda contra o uso distorcido do impeachment.

As reflexões sobre o presente tema têm muito a ganhar com os aportes do Direito Constitucional Comparado e do perene convite ao diálogo que ele representa. Nesse sentido, registre-se que cada vez mais se identifica a necessidade de que nos processos interpretativos das normas constitucionais - sede por excelência, por exemplo, das regras e procedimentos sobre impeachment - se proceda ao diálogo atento e franco com o Direito Internacional dos Direitos Humanos ${ }^{27}$.

O fenômeno que a OC pretende investigar e evitar mediante o SIDH - o uso desvirtuado de instituições democráticas que pode, por sua vez, colocar em xeque o funcionamento das democracias constitucionais - tem sido objeto de intensas reflexões ${ }^{28}$. Nesse sentido, aponta-se para o perigo representado pela maior polarização na política ordinária ${ }^{29}$ e para a falta de autocontenção no exercício dos instrumentos à disposição para o exercício do poder ${ }^{30}$.

Feitas essas considerações iniciais, tem-se que os diálogos podem ser praticados em diferentes níveis, e se consubstanciam na prática de cortes domésticas e internacionais usarem fundamentos e precedentes de outras jurisdições para a construção de uma melhor interpretação acerca de determinada norma legal contida em uma constituição ou tratado. A partir da interação entre diferentes jurisdições, o diálogo busca promover a otimização dos parâmetros nacionais e internacionais de proteção dos direitos humanos ${ }^{31}$.

A solicitação da OC pretende "transcender as especificidades de casos concretos e permitir uma abordagem geral” sobre o tema dos juízos políticos, o que pode ser proporcionado por meio dos diálogos, sejam horizontais ou verticais. No presente caso, recorrer aos diálogos possibilita fornecer meios de que se alcance a coerência na aplicação e interpretação das normas legais atinentes aos direitos humanos e suas garantias de devido processo legal e direito à justiça.

A partir dos diálogos interinstitucionais é possível delinear critérios de congruência normativa. Estas aproximações, contudo, não pretendem produzir uma uniformização absoluta, posto que uma de suas características inerentes é a flexibilidade. A abertura a jurisdições de diferentes Cortes possibilita o

\footnotetext{
${ }^{27}$ Nesse sentido: Yuval Shany. How supreme is the supreme law of the land? Comparative analysis of the influence of internacional human rights treaties upon the interpretation of constitutional texts by domstic courts, Brooklyn Journal of Internacional Law, V. 31, No. 2, 2006, p. 354, e André de Carvalho Ramos, Curso de Direitos Humanos, $3^{\mathrm{a}}$ Ed, Saraiva, São Paulo, 2016, p. 430 et seq.

28 Exemplificativamente, as discussões propostas por Mark Tushnet sobre as bolas divididas constitucionais (“Constitutional Hardball”) ou sobre o apodrecimento constitucional (“Constitutional Rot”) propostas por Jack M. Balkin: Tushnet, Mark, Constitutional Hardball. John Marshall Law Review, forthcoming. Disponível em: <https://ssrn.com/abstract=451960>; Balkin, Jack M., Constitutional Rot (June 14, 2017). Can It Happen Here? Authoritarianism in America, Cass R. Sunstein, ed. (2018, Forthcoming); Yale Law School, Public Law Research Paper No. 604. Disponível em: <https://ssrn.com/abstract=2992961>.

${ }^{29}$ Nesse sentido: Cass R. Sunstein. Going to extremes: How like minds unite and divide. Oxford University Press, New York, 2009.

${ }^{30}$ A maior polarização política - somada à percepção de que os opositores políticos são inimigos e não concidadãos com pontos legítimos com os quais se discorda - e a utilização dos instrumentos constitucionais para se entrincheirar no poder de forma a evitar, a todo custo, que a agenda do "inimigo" tenha espaço no exercício do poder são pontos que Levitsky e Ziblatt apontam como preocupantes e contrários à manutenção da democracia. Ver: Steven Levitsky e Daniel Ziblatt. How democracies die. Crown Publishing, New York, 2018.

${ }^{31}$ Eduardo Ferrer MacGregor. What do we mean when we talk about judicial dialogue? Reflections of a judge of the Inter-American Court of Human Rights. Harvard Human Rights Journal, V. 30, set./dez. 2017, p. 90-91.
} 
contato com uma diversidade de critérios e decisões de juízes que enfrentaram questões similares em diferentes contextos ${ }^{32}$.

O primeiro sentido de aproximação nesta matéria deve levar em conta o sentido histórico de sua localização, bem como sua relação com as decisões políticas fundamentais.

A possibilidade de julgamento político de altas autoridades públicas está presente de maneira consolidada em diversos Estados que adotam o sistema presidencialista, provavelmente sendo esse o principal tipo de regime contemporâneo associado à ideia de impeachment. Contudo, ela não é uma modalidade exclusiva do presidencialismo e, curiosamente, sua origem pode ser traçada primariamente a um regime específico que nunca assistiu à eleição e posse de um presidente: a monarquia constitucional britânica ${ }^{33}$.

Todavia, no âmbito do constitucionalismo moderno, é a partir da Constituição estadunidense que o julgamento político ganha contornos jurídico-institucionais, particularmente no âmbito de um sistema presidencialista. Portanto, a análise da relação entre julgamentos políticos, democracia e o regime presidencialista demanda um olhar para fora, seja na comparação das realidades constitucionais (diálogos horizontais), seja na aferição dos precedentes dos países que compõem o sistema interamericano (diálogos verticais). É o que se passa a fazer, após breve advertência quanto ao uso das expressões juízos políticos e impeachment.

\subsection{NOMENCLATURA: JUÍZOS POLÍTICOS OU IMPEACHMENT?}

Faz-se necessária uma advertência prévia quanto à nomenclatura. É importante destacar que a OC não utiliza o termo impeachment de maneira ostensiva. A consulta aplica, efetivamente, o termo impeachment ao identificá-lo como fonte de inspiração de “julgamento político". Em outro momento, realiza uma identificação entre o termo impeachment e julgamento político ${ }^{34}$. Em realidade, ainda que a expressão inglesa tenha sido amplamente incorporada pela academia, opinião pública e meios de comunicação brasileiros, a Constituição brasileira não toma emprestado o termo inglês uma só vez em seu texto. É certo que sua inserção primeira na Constituição dos EUA se faz por meio do termo “impeachment”, retomando certa tradição política no mundo anglo-saxão. A opção pela não utilização do termo em inglês nos textos constitucionais dos países que compõem o SIDH é replicada em praticamente todas as constituições latino-americanas, ainda que - como analisaremos em seguida o convite ao paralelismo entre o impeachment do constitucionalismo estadunidense e o julgamento político de outros Estados do continente americano seja bem natural, como observa a OC.

\footnotetext{
${ }^{32}$ Eduardo Ferrer MacGregor, What do we mean when we talk about judicial dialogue?, op. cit., p. 97.

33 Sunstein relata que em 1679, aproximadamente cem anos antes da independência dos EUA, a House of Commons, órgão do parlamento britânico, proclamou o impeachment como "the chief institution for the preservation of the government" e que Edmund Burke teria descrito o impeachment como "the great guardian of the purity of the Constitution.” No caso, evidentemente, o impeachment não era concebido como instrumento voltado contra o rei, mas sim contra os seus ministros. Cass R. Sunstein. Impeachment: a citizen’s guide. Harvard University Press, Cambridge, 2017, p. 35. O autor argumenta, ainda, que o instituto do impeachment já era utilizado pelas colônias norte-americanas para lutar contra prerrogativas reais, sendo o instrumento mediante o qual as legislaturas coloniais atacavam o que viam como governança ilegítima. Com a independência, ele se tornaria o mecanismo republicano para controlar os agentes públicos que abusavam de seu poder. Cass R. Sunstein, Impeachment, op. cit., p. 2.

${ }^{34}$ Ver CIDH. Democracia e direitos humanos no contexto de julgamentos políticos. Solicitação de parecer consultivo à Corte Interamericana de Direitos Humanos, par. 17 e 18.
} 
Por outro lado, a OC enfatiza o termo "julgamento político”. Uma relevante questão conceitual a ser destacada é que nem sempre as constituições regionais lançam mão, de maneira explícita e clara, do uso desse termo.

Em síntese, é possível aferir três possibilidades em que poderá ser feito um “juízo político” pelo Poder Legislativo dos regimes presidencialistas da região, que poderão, de algum modo, afetar a estabilidade e término natural do mandato presidencial:

(i) a responsabilização político-administrativa do Presidente da República - a que denominaremos, para fins deste AC, como o julgamento político propriamente dito ou impeachment;

(ii) a autorização e processamento penal do Presidente da República pelo cometimento de crimes, comuns ou não;

(iii) a declaração de incapacidade física e mental para a continuidade do exercício da Presidência da República ${ }^{35}$.

As três hipóteses não estão necessariamente previstas em todas as constituições do continente americano, existindo um espectro significativo de variações. O objeto da presente OC, investigado neste $\mathrm{AC}$, diz respeito à hipótese (i).

\subsection{APROXIMAÇÃO: PRESIDENCIALISMO?}

A OC tenta realizar uma distinção entre "voto de censura ou falta de confiança”, típico do regime parlamentarista, e "julgamento político", em que o "voto de censura” seria "expressão de uma desaprovação ou falta de confiança na gestão ou no desempenho político de altos funcionários; de onde a referência à responsabilidade política"36. Contudo, diante de algumas das provisões constitucionais citadas pela própria OC, essa divisão é assaz tênue e, em alguns casos, sobrepõe-se à noção de julgamento político. A OC parece reconhecer isso, ao citar os casos do Paraguai e da Argentina $^{37}$.

Se algumas constituições, ainda que adotem o regime presidencialista, optaram por utilizar conceitos como "mau desempenho" para fins de avaliação e mesmo eventual destituição do presidente da república, isso faz parte do que se considera uma válvula de escape, constitucionalmente válida, em regimes presidencialistas para se remover um presidente antes do término natural de seu mandato quando há razões jurídico-políticas para tanto. Trata-se de um elemento norteador da relação entre o Executivo e Legislativo, e um mecanismo que tais constituições elegeram para possibilitar a solução constitucional para escapar de graves crises institucionais.

Isso não quer dizer que seja uma saída constitucional adequada para todas as comunidades políticas da região. O fato de algumas delas entenderem ser tais válvulas adequadas para o seu contexto e circunstância política não deixa de exprimir a escolha de um caminho constitucionalmente legítimo para regrar o sistema presidencialista adotado.

Um ponto a se destacar e que está presente nas concepções políticas subjacentes é que o mecanismo do impeachment e do julgamento político é uma arma política, usada para desafiar os erros oficiais. Diante de um Poder Executivo forte, esse instrumento atua, segundo Sunstein, como "nosso sistema

\footnotetext{
${ }^{35} \mathrm{Na}$ Constituição estadunidense, essa hipótese foi incluída pela 25ª Emenda à Constituição.

${ }^{36}$ Ver CIDH, Democracia e direitos humanos no contexto de julgamentos políticos, op. cit., par. 19.

${ }^{37}$ Ver CIDH, Democracia e direitos humanos no contexto de julgamentos políticos, op. cit., par. 24.
} 
de segurança, nosso escudo, nossa espada - nossa arma máxima para autodefesa" 38 . Serrafero afirma ainda que exercitar e tornar efetiva a responsabilidade política dos governantes figura como elemento conatural e essencial do "bom governo"39.

Em estudo comparativo em regimes presidenciais da América Latina abrangendo o período 19502000, é interessante destacar que Pérez-Liñán concluiu que a perda da habilidade do Presidente em desafiar o Legislativo em crises constitucionais tende a significar mais o amadurecimento da democracia, quando uma relação mais balanceada eventualmente se desenvolve. Isso se destaca principalmente quando rompe com a tradição enraizada de dominância do Executivo, que historicamente caracterizou a região ${ }^{40}$.

Certamente, isso não significa dizer que a previsão e utilização do mecanismo de impeachment possa admitir abusos por parte do Poder Legislativo, principalmente nos casos em que o Poder Legislativo é controlado por partido(s) ou coalizão que se opõe(m) ao Presidente da República.

É importante destacar que, em regimes constitucionais legítimos, os titulares de mandato no Poder Legislativo também são democraticamente eleitos e, nesse sentido, é no mínimo complexo concluir que, quando se utilizam de instrumentos disponibilizados pela própria Constituição, estariam automaticamente agindo de maneira autoritária ou não democrática, e não em preservação da continuidade institucional ou democrática em um momento de grave crise constitucional ${ }^{41}$.

No nó da relação Executivo e Legislativo reside a inquietação: quem possuiria legitimidade para controlar o julgamento político do Presidente da República realizado pelo Poder Legislativo, e sob quais fundamentos? ${ }^{42}$

\subsection{ORIGEM COMUM, SENTIDO PLURAL}

O julgamento político como responsabilização político-administrativa aproxima-se do impeachment anglo-saxão e diversas constituições adotadas nas Américas parecem ter se inspirado, na disciplina normativa inserida na Constituição estadunidense, se não materialmente, ao menos quanto aos aspectos procedimentais básicos. Isso ocorre principalmente nos países em que o Poder Legislativo é exercido de modo bicameral por uma câmara dos deputados e um senado (ou câmara do senado).

\footnotetext{
38 Tradução livre de Cass R. Sunstein, Impeachment, op. cit., p. 174: “our fail-safe, our shield, our sword - our ultimate weapon for self-defense”.

39 Mario D. Serrafero. El “Impeachment” en America Latina: Argentina, Brasil y Venezuela. Revista de Estudios Politicos (Nueva Epoca), V. 92, abr./jun., 1996, p. 137-162. Disponível em: <https://goo.gl/mGehyi>.

40 Anival, Pérez-Liñan. Democratization and constitutional crises in presidential regimes: Towards congressional supremacy? Comparative Political Studies, V. 38, fev. 2005, p. 51-74.

${ }^{41}$ Nesse sentido, Serrafero destaca ainda que o impeachment pode ser focado sob duas óticas: (i) mecanismo de controle político-institucional; ou (ii) mecanismo ao serviço da continuidade institucional, quando a permanência do agente político implica um sério risco para o funcionamento do sistema. Mario D. Serrafero, El “Impeachment” en America Latina, op. cit, p. 139.

${ }^{42}$ Essa também é uma inquietação presente nos Estados Unidos. No capítulo 9 o de seu livro sobre impeachment - "O que todos os americanos deveriam saber" ("What every American should know”), Sunstein adota um modelo de perguntas e respostas, em que, em dado momento, levanta a seguinte questão: "Não seria o impeachment apenas uma questão política e, em caso afirmativo, por que deveríamos nos concentrar tanto na regra jurídica?” (“Isn’t impeachment just a matter of politics, and if so, why should we focus so much on the legal standard?”). O próprio autor responde, afirmando que: “A compreensão dos motivos legítimos para o impeachment impõe um efeito regulatório sobre o processo político” (“An understanding of the legitimate grounds for impeachment imposes a disciplining effect on the political process.”). Ver: Cass R. Sunstein, Impeachment, op. cit., p. 159-160.
} 
No cenário latino-americano, busca-se a construção de um Ius Constitucionale Commune, almejando, tanto do direito positivo como do discurso jurídico a seu respeito, uma abordagem assente nas experiências concretas dos países, cujas violações de direitos humanos advêm de déficits sistêmicos. A este respeito, Armin Von Bogdandy sustenta que a vocação do Ius Commune latino-americano é eminentemente prática, e tem o escopo de concretizar as garantias presentes nas constituições da região $0^{43}$.

O Direito Constitucional tem aqui um potencial emancipador, mesmo diante das significativas discrepâncias entre o texto e a realidade. Ao invés de aparecer como óbice à discussão, constituía razão para que os desafios fossem enfrentados ${ }^{44}$. O diálogo inter-regional empreendido pela análise de precedentes de Cortes e Tribunais que também leve em consideração suas experiências negativas pode contribuir para a construção de um sistema cada vez mais direcionado ao fortalecimento dos direitos humanos.

Os juízos políticos podem servir à democracia ou ser prejudiciais a ela, e a consulta formulada busca estabelecer critérios para avaliar situações em que são exercidos de forma válida e quando são utilizados indevidamente. Esta análise comparada e dialogal é indispensável, inclusive porque um dos questionamentos formulados pela OC versa sobre como o controle judicial poderia não implicar um risco à separação de Poderes e ao sistema de freios e contrapesos, e sobre quais salvaguardas poderiam haver para prevenir o uso de juízos políticos na forma de golpe de Estado encoberto.

O instituto do impeachment, como desenhado na Constituição estadunidense, deixou profundas marcas nas constituições da região. Para os Estados que adotaram o modelo bicameral no Poder Legislativo, a iniciativa do impeachment cabe à câmara dos deputados ${ }^{45}$ e a condução do julgamento dá-se no senado. Esse modelo é mantido em praticamente todas as constituições da região - Argentina (art. 59), Brasil, Chile (art. 52, [2] e 53), Colômbia (art. 174 e 178 [3]) ${ }^{46}$, México (arts. 74, 76 e $111^{47}$ ), Nicarágua (art. 140 e 145), Paraguai (art. 225) e Uruguai (arts. 93 e 102).

Em alguns países que adotaram o unicameralismo (e.g., Equador e Peru), o papel de acusação e admissibilidade atribuído à câmara dos deputados em sistemas bicamerais é exercido por distintos órgãos. No Equador, embora a acusação deva ser aprovada por um terço dos membros do Congresso, o juízo de admissibilidade é exercido pela Corte Constitucional, cabendo o julgamento à Assembleia Nacional (art. 129). No Peru, por sua vez, o papel atribuído à House of Representatives estadunidense é substituído pela Comissão Permanente (art. 99), órgão do Congresso. Cabe, porém, ao plenário do Congresso o julgamento quanto à suspensão e destituição das autoridades públicas.

Nem toda as constituições, no entanto, preveem expressamente o rito de julgamentos políticos propriamente dito (impeachment), embora prevejam a participação do Poder Legislativo em caso de acusações de delitos contra o Presidente da República. Esse é o caso dos seguintes países: Bolívia (art. 184[4]), El Salvador (art. 236), Guatemala (art. 165, 'h’), Honduras e Nicarágua.

\footnotetext{
${ }^{43}$ Armin Von Bogadandy. Ius Constitutionale Commune na América Latina: marco conceptual. Curitiba, Juruá, 2016.

${ }^{44}$ Armin Von Bogadandy, Ius Constitutionale Commune na América Latina, op. cit., p. 23.

${ }^{45}$ Variações de nomenclatura incluem também 'Câmara de Representantes’, e.g., Colômbia e Uruguai.

${ }^{46}$ Na Constituição colombiana, mesmo no âmbito da Câmara dos Representantes, há análise e solicitação prévia pela Comisión de Investigación y Acusación.

47 "Si la Cámara declara que ha lugar a proceder, el sujeto quedará a disposición de las autoridades competentes para que actúen con arreglo a la ley. Por lo que toca al Presidente de la República, sólo habrá lugar a acusarlo ante la Cámara de Senadores en los términos del artículo 110. En este supuesto, la Cámara de Senadores resolverá con base en la legislación penal aplicable.” (grifo nosso).
} 
De acordo com a Constituição dos EUA, as razões que justificam o impeachment, sob uma perspectiva material, seriam “traição, suborno, ou outros delitos e contravenções graves" 48 . A partir da disposição constitucional e das discussões sobre seu conteúdo à época em que promulgada, Sunstein aponta que o impeachment é aplicável para abusos graves de autoridade oficial ${ }^{49}$. Diversas constituições do continente americano estabelecem enumeração de hipóteses que poderiam implicar o julgamento político do Presidente.

Para facilitar a visualização, segue abaixo quadro esquemático com remissão aos dispositivos pertinentes, a fim de facilitar a comparação das principais expressões utilizadas pelas constituições da região:

\begin{tabular}{|c|c|}
\hline na & rt. 53 - “Mal desempeño o por delito en el ejercicio de sus funciones” (art. 53) \\
\hline Chile & $\begin{array}{l}\text { Art. 52, 2, 'a’ - “actos de su administración que hayan comprometido gravemente el } \\
\text { honor o la seguridad de la Nación, o infringido abiertamente la Constitución o las } \\
\text { leyes” }\end{array}$ \\
\hline Colô & $\begin{array}{l}\text { Art. } 175 \text { (2) - “delitos cometidos en ejercicio de funciones”, “indignidad por mala } \\
\text { conducta” e "causas constitucionales" }\end{array}$ \\
\hline Rica & $\begin{array}{l}\text { Art. } 149 \text { - "responsabilidad" " } 1 \text {. Cuando comprometan en cualquier forma la libertad, } \\
\text { la independencia política o la integridad territorial de la República; } 2 \text {. Cuando impidan } \\
\text { o estorben directa o indirectamente las elecciones populares, o atenúen contra los } \\
\text { principios de alterabilidad en el ejercicio de la presidencia o de la libre sucesión } \\
\text { presidencial, o contra la libertad, orden o pureza del sufragio; 3. Cuando impidan o } \\
\text { estorben las funciones propias de la Asamblea Legislativa, o coarten su libertad e } \\
\text { independencia; } 4 \text {. Cuando sé nieguen a publicar o ejecutar las leyes y demás actos } \\
\text { legislativos. 5. Cuando impidan o estorben las funciones propias del Poder Judicial o } \\
\text { coarten a los Tribunales la libertad con que deben juzgar las causas sometidas a su } \\
\text { decisión o cuando obstaculicen en alguna forma las funciones que corresponden a los } \\
\text { organismos Electorales o a las municipales. } 6 \text {. En todos los demás casos en que por } \\
\text { acción u omisión viole el poder ejecutivo alguna ley extraña." }\end{array}$ \\
\hline Eq & $\begin{array}{l}\text { Art. } 129 \text { - “enjuiciamiento político de la Presidenta o Presidente, o de la } \\
\text { Vicepresidenta o Vicepresidente de la República” pelos siguientes actos: “1. Por } \\
\text { delitos contra la seguridad del Estado. 2. Por delitos de concusión, cohecho, peculado } \\
\text { o enriquecimiento ilícito. 3. Por delitos de genocidio, tortura, desaparición forzada de } \\
\text { personas, secuestro u homicidio por razones políticas o de conciencia.” }\end{array}$ \\
\hline & $\begin{array}{l}\text { Art. } 76 \text { - “juicio político” - “faltas u omisiones que cometan los servidores públicos y } \\
\text { que redunden en perjuicio de los intereses públicos fundamentales y de su buen } \\
\text { despacho” } \\
\begin{array}{l}\text { Art. } 108 \text { - “El Presidente de la República, durante el tiempo de su encargo, sólo podrá } \\
\text { ser acusado por traición a la patria y delitos graves del orden común.” }\end{array}\end{array}$ \\
\hline
\end{tabular}

\footnotetext{
${ }^{48}$ No original: "The President, Vice President and all civil Officers of the United States, shall be removed from Office on impeachment for, and Conviction of, Treason, Bribery, or other high Crimes and Misdemeanors”.

${ }^{49}$ Cass R. Sunstein, Impeachment, op. cit., p. 54-56.
} 


\begin{tabular}{|l|l|}
\hline Panamá & $\begin{array}{l}\text { Art. } 160 \text { - “perjuicio del libre funcionamiento del poder público o violatorio de esta } \\
\text { Constitución o las leyes” (art. 160) e, no capítulo sobre o Poder Executivo, estipula } \\
\text { como conductas de responsabilidad "extralimitación de sus funciones } \\
\text { constitucionales”, "por actos de violencia o coacción en el curso del proceso electoral; } \\
\text { por impedir la reunión de la Asamblea Nacional; por obstaculizar el ejercicio de las } \\
\text { funciones de esta o de los demás organismos o autoridades públicas que establece la } \\
\text { Constitución” e “por delitos contra la personalidad internacional del Estado o contra } \\
\text { la Administración Publica”. }\end{array}$ \\
\hline Paraguai & $\begin{array}{l}\text { Art. } 225 \text { - “juicio político por mal desempeño de sus funciones, por delitos cometidos } \\
\text { en el ejercicio de sus cargos o por delitos comunes.” }\end{array}$ \\
\hline Peru & $\begin{array}{l}\text { Art. } 99 \text { - “infracción de la Constitución y por todo delito que cometan en el ejercicio } \\
\text { de sus funciones” }\end{array}$ \\
\hline Uruguai & Art. 93 - “juicio público” por “violación de la Constitución u otros delitos graves” \\
\hline
\end{tabular}

A análise dos dispositivos de cada país permite vislumbrar as semelhanças e divergências existentes entre eles. As condenações anteriores da Corte IDH em razão de violações a garantias de devido processo legal e direito à justiça demonstram que as experiências regionais ligadas à democracia, direitos humanos e Estado de Direito (rule of law), quando levadas em consideração, podem fazer com que determinada jurisdição se abstenha de praticar atos lesivos à instituição do impeachment, como adiantado na abertura desta seção do AC.

A linguagem do diálogo, dessa forma, representa uma medida civilizada e respeitosa de resolução de conflitos em momentos de antagonismo político ${ }^{50}$. O modelo dialógico do constitucionalismo ameniza o sistema de freios e contrapesos, já que tenciona “conter a confrontação" em vez de promover a aprendizagem e ajuda mútuas ${ }^{51}$. O mesmo se passa em relação aos constitucionalismos e o sistema regional. É o que se passa a demonstrar, a partir dos diálogos verticais.

\subsection{DIÁLOGOS VERTICAIS}

Tratando-se dos diálogos jurisdicionais verticais, ou seja, aqueles realizados entre a Corte IDH e os tribunais nacionais dos países signatários da $\mathrm{CADH}$, cumpre atentar ao seu caráter contemporâneo, como um fenômeno emergente da prática dos tribunais, diretamente atrelado à constitucionalização do direito internacional dos direitos humanos e à internacionalização do direito constitucional dos Estados.

Esse fenômeno se desenvolve não só a partir de uma concepção dos direitos humanos como living instrument - interpretado dinâmica e evolutivamente, à luz dos tempos atuais - como também por meio da promoção do princípio pro personae, que prevê a aplicabilidade da norma de máxima proteção, ou seja, aquela que melhor tutela o bem jurídico violado.

Nesse sentido, o diálogo vertical entre Cortes tem beneficiado a proteção dos direitos humanos, sobretudo com o robustecimento do controle de convencionalidade - importante ferramental para que os ordenamentos internos dos Estados signatários adequem suas normas à luz da CADH. Esse

\footnotetext{
${ }^{50}$ Roberto Gargarella. El nuevo constitucionalismo dialógico, frente al sistema de los frenos y contrapesos. In: Por una justicia dialógica. Siglo XXI, Buenos Aires, 2014, p. 3.

${ }^{51}$ Roberto Gargarella, El nuevo constitucionalismo dialógico, frente al sistema de los frenos y contrapesos, op. cit., p. 14.
} 
instituto jurídico tem como base normativa o artigo $2^{\circ}$ da CADH, o qual dispõe que "se o exercício dos direitos e liberdades mencionados no artigo 1 ainda não estiver garantido por disposições legislativas ou de outra natureza, os Estados Partes comprometem-se a adotar, de acordo com as suas normas constitucionais e com as disposições desta Convenção, as medidas legislativas ou de outra natureza que forem necessárias para tornar efetivos tais direitos e liberdades”.

Assim, o controle de convencionalidade possibilita a interação e o diálogo jurisdicional vertical, fruto do comprometimento internacional do Estado Parte em adotar disposições de direito interno que coadunem com o corpus juris interamericano. É o que recentemente afirmou a própria Corte IDH, quando da Opinião Consultiva n ${ }^{\circ} 24 / 17$, no voto concorrente do Juiz Eduardo Vio Grossi ${ }^{52}$.

O controle de convencionalidade, portanto, contribui para a efetividade dos diálogos entre a Corte IDH e os tribunais nacionais, como uma importante ferramenta de incorporação dos standards convencionais no direito interno. Cada Estado Parte tem, a partir do corpus juris interamericano, o poder-dever de expandir o nível de proteção dos direitos humanos abarcados por sua legislação interna, não havendo limitação por parte do direito internacional dos direitos humanos.

Dessa forma, é fundamental para o diálogo americano, em termos de consolidação da democracia e densificação dos juízos políticos, conhecer bem a jurisprudência do sistema.

\subsection{PRECEDENTES DO SIDH: DELINEANDO O FUTURO DO TEMA}

No que tange ao diálogo vertical, mais especificamente entre a Corte Interamericana de Direitos Humanos e os ordenamentos jurídicos latino-americanos, dois casos julgados pela Corte merecem destaque. Trata-se dos casos “Tribunal Constitucional Vs. Peru”, de janeiro de 2001, e "Tribunal Constitucional Vs. Equador”, de agosto de 2013.

Ambos os precedentes dizem respeito ao afastamento de membros de tribunais e cortes nacionais, por meio de resoluções emitidas pelos Congressos Nacionais do Peru e do Equador, respectivamente. Não se tem notícia de casos em que a Corte Interamericana tenha se debruçado sobre julgamentos políticos de chefes do Poder Executivo na região. De qualquer sorte, a partir dos dois casos é possível extrair que, nas palavras da Corte, a noção de democracia substancial pressupõe uma dimensão objetiva $^{53}$, relacionada a aspectos essenciais do Estado de Direito. Esses elementos seriam, notadamente, o princípio da separação entre os Poderes e a importância da função judicial numa democracia.

Ainda, convém rememorar o art. $3^{\circ}$ da Carta Democrática Interamericana, segundo o qual "são elementos essenciais da democracia representativa, entre outros, o respeito aos direitos humanos e às liberdades fundamentais, o acesso ao poder e seu exercício com sujeição ao Estado de Direito, a celebração de eleições periódicas, livres, justas e baseadas no sufrágio universal e secreto como

\footnotetext{
${ }^{52}$ Corte IDH. Opinión Consultiva OC-24/17 de 24 de noviembre de 2017. Serie A No. 24. Párr. 115: "Así, entonces, el control de convencionalidad consiste, en definitiva, en la comparación de una norma o práctica nacional con lo dispuesto por la Convención, a los efectos de determinar la compatibilidad de aquella con ésta y, consecuentemente, de la preeminencia de una respecto de la otra en el evento de contradicción entre ambas y, obviamente, la respuesta dependerá de si la proporciona un órgano del pertinente Estado Parte de la Convención de manera previa a la intervención de la Corte o si es ésta la que la emite con posterioridad o cuando aquél no ha realizado el mencionado control".

${ }^{53}$ Corte IDH. Caso do Tribunal Constitucional (Camba Campos e outros) Vs. Equador. Exceções Preliminares, Mérito, Reparações e Custas. Sentença de 28 de agosto de 2013. Série C, nº 268, par. 198.
} 
expressão da soberania do povo, o regime pluralista de partidos e organizações políticas, e a separação e independência dos poderes públicos”54.

O caso "Tribunal Constitucional Vs. Peru" integra aquilo que se convencionou chamar de "ciclo de casos peruanos" 55 da Corte, cujo eixo comum diz respeito ao reconhecimento de graves violações de direitos humanos cometidos pelo Estado do Peru quando da presidência de Alberto Fujimori (19902000).

O mérito da controvérsia diz respeito ao afastamento de três juízes da Corte Constitucional do Peru (Manuel Aguirre Roca, Guillermo Rey Terry y Delia Revoredo Marsano) por parte do Congresso Nacional, incluindo entre eles a sua então presidente. O afastamento deu-se sob o fundamento de que tais magistrados teriam violado seus respectivos deveres funcionais ao votarem pela inconstitucionalidade de uma interpretação da legislação eleitoral que permitiria ao presidente Alberto Fujimori disputar um terceiro mandato presidencial.

O afastamento dos magistrados ocorreu em tempo célere, formalizado por meio de resoluções emitidas pelo Congresso Nacional em 28 de maio de 1997 (Resoluções nº 002-97-CR, 003-97-CR y 004-97-CR), três semanas após a apresentação de denúncia pela Comissão Investigativa montada em janeiro do mesmo ano. A anulação das destituições só foi levada a cabo pelo Parlamento peruano em 17 de novembro de 2000, reinstalando os magistrados em seus cargos.

A Corte IDH, ao apreciar comunicação feita pelo Colégio de Advogados de Lima, processada pela $\mathrm{CIDH}$, decidiu que os artigos $8^{\circ}$ e 25 da CADH foram violados pelo Estado do Peru. Com relação ao artigo $8^{\circ}$, a Corte salientou que "en el caso sub judice sucedieron los vicios apuntados (supra 80), lo cual no permitió a los magistrados contar con un proceso que reuniera las garantías mínimas del debido proceso establecidas en la Convención. Con ello en el caso en estudio se limitó el derecho de las víctimas a ser oídas por el órgano que emitió la decisión y, además, se restringió su derecho a participar en el proceso".

A conclusão da violação ao devido processo legal adveio da conjugação de diversos fatores, notadamente: (i) o desconhecimento, pelos acusados, da plenitude das acusações contra eles formuladas; (ii) o prazo de defesa extremamente curto; (iii) a proibição de participar da instrução probatória do processo de impeachment, formulando perguntas às testemunhas; e (iv) a ausência de condições referentes à imparcialidade e independência dos membros do Poder Legislativo responsáveis pelo julgamento político.

Naquela ocasião, quanto à interpretação do artigo 25, a Corte IDH entendeu que o direito a um recurso efetivo foi violado, uma vez que os atos de destituição dos magistrados poderiam ser impugnados pela via judicial, analisando o respeito às garantias do devido processo penal, sem prejuízo de se observar o caráter estritamente político da decisão proferida pelo Poder Legislativo.

O caso “Tribunal Constitucional Vs. Equador” envolveu a análise de fatos que ocorreram quando o Equador se encontrava numa situação de instabilidade política, que havia implicado a remoção de vários Presidentes e a modificação da Constituição visando tentar controlar a crise política. Para melhor compreensão do precedente, faz-se breve relato dos fatos discutidos.

\footnotetext{
${ }^{54}$ Carta Democrática Interamericana. Disponível em: <https://goo.gl/FhyoTm>.

55 Ana Salado Osuna. Las sentencias de fondo de la Corte Interamericana de Derechos Humanos en los casos peruanos. Disponível em: <http://www.corteidh.or.cr/tablas/R08066-4.pdf>.
} 
Em novembro de 2004, o então Presidente da República, Lucio Gutiérrez, anunciou o propósito do governo em impulsionar no Congresso a reorganização do Tribunal Constitucional, do Tribunal Supremo Eleitoral e da Corte Suprema de Justiça. O Tribunal Constitucional emitiu, então, comunicado na imprensa, no sentido de que seus membros estariam dispostos a responder pelos atos realizados no exercício de suas funções ou pelas omissões mediante o processo constitucional (juízo político), e não por mera resolução, o que implicaria violação do Estado Social de Direito.

O Presidente do Congresso, então, convocou os membros do Tribunal Constitucional a comparecerem a um juízo político agendado para o dia $1^{\circ}$ de dezembro de 2004, iniciado por alguns congressistas que eram contra algumas decisões adotadas pelo referido tribunal. Uma dessas decisões tinha relação com a lei que implantava o " $14^{\circ}$ salário" e fora declarada inconstitucional pelo Tribunal, já que seria de iniciativa privativa do Presidente da República. A outra principal decisão, por sua vez, era relacionada ao sistema de alocação de cadeiras eleitorais, conhecido como o “método D’Hondt”, que, de acordo com o Tribunal Constitucional, distorcia a intenção do eleitorado nos países que possuem sistemas eleitorais com listas abertas.

De maneira concomitante, o Congresso aprovou uma resolução (Resolução $n^{\circ} \mathrm{R}-25-160$ ), mediante a qual foi determinado que os atuais membros do Tribunal haviam sido designados de forma ilegal em 2003 e, portanto, deveriam ser imediatamente destituídos de suas funções. Os membros do Tribunal não foram notificados antes dessa sessão, nem, consequentemente, tiveram o seu direito à manifestação prévia respeitado.

Após a destituição, na sessão do dia $1^{\circ}$ de dezembro de 2004, os ex-membros do Tribunal tiveram a oportunidade de se manifestar. Na ocasião explicaram as razões das decisões questionadas e destacaram a ilegalidade de estabelecer responsabilidades pelo voto em um ou outro sentido no âmbito do Tribunal. Naquela oportunidade nenhuma moção foi aprovada.

No dia cinco de dezembro de 2004, por sua vez, o Presidente da República convocou o Congresso Nacional para uma sessão extraordinária, que aconteceu no dia 8 seguinte. Nessa sessão foi aprovada a censura dos ex-membros do Tribunal Oswaldo Cevallos, Jaime Nogales, Miguel Camba, Luis Rojas, Simón Zavala e Manuel Jaramillo, novamente sem que pudessem se manifestar. A razão da censura foi a decisão tomada no caso do "método D’Hondt”. Nenhuma moção foi aprovada em relação ao caso do " $14^{\circ}$ salário”.

A Corte IDH inicialmente ratificou as rationes decidendi adotadas no caso "Tribunal Constitucional Vs. Peru”. Dessa forma, para analisar se a resolução e o juízo político por parte do Congresso foram ou não arbitrários, levou em consideração a competência do Congresso para destituir membros do Tribunal Constitucional, bem como o alcance do direito a ser ouvido, e os standards gerais sobre a independência judicial. Tudo isso à luz da dimensão institucional da independência judicial, a partir da separação de Poderes e da democracia.

Nesse sentido, a Corte determinou, em relação à competência do Congresso, que se este considerou que a nomeação dos membros do Tribunal Constitucional se deu de forma ilegal, não deveria tê-lo assentado apenas um ano e meio após a nomeação. Para a Corte, essa demora afetaria sobremaneira a garantia de estabilidade no cargo, permitindo pressões externas, aspectos que impactariam diretamente na independência judicial.

Quanto ao direito de ser ouvido, a Corte IDH ressaltou que os membros do Tribunal Constitucional não foram notificados da discussão sobre as irregularidades sobre sua designação, não sendo 
conferido a eles o direito de responderem às acusações no Congresso. Ademais, entendeu que quando há um juízo político, é necessário que sejam postos em termos claros quando este se inicia e quando é finalizado. Para a Corte, a votação realizada no dia oito de dezembro de 2004 reabriu juízo político que já havia sido previamente finalizado.

Sobre a independência judicial, a Corte IDH novamente assentou que para que haja destituição de um juiz é preciso que se verifiquem condutas graves, especialmente considerando as garantias da estabilidade e inamovibilidade do cargo. Assim, para a Corte, o objetivo de um juízo político conduzido pelo Congresso Nacional não poderia ser o afastamento de um membro do Tribunal em razão da revisão da constitucionalidade ou legalidade de sentenças por ele adotadas ${ }^{56}$.

No que interessa para a presente OC, esses foram os termos em que os Estados do Peru e do Equador foram condenados por violações aos artigos $8^{\circ}$ e 25 (proteção judicial) da Convenção ${ }^{57}$.

\subsection{DIÁLOGOS HORIZONTAIS: BREVE RELATO DOS PROCESSOS DE JULGAMENTO POLÍTICO OU IMPEACHMENT NO ÂMBITO LATINO- AMERICANO. OS RECENTES CASOS DO PARAGUAI, HONDURAS, PERU E BRASIL}

Como adiantado nas seções e itens anteriores deste AC, a presente OC não deve constituir um préjulgamento de casos que pendem de análise pela CIDH. De outro lado, é fora de dúvida a relevância e atualidade da preocupação da Comissão e da Corte sobre os processos de impeachment contra chefes do Poder Executivo nos países que compõem o SIDH. Dessa forma, uma exposição analítica do modo como alguns processos de impeachment recentes têm transcorrido no âmbito regional colabora para a maior densificação que se pretende conferir aos artigos $8^{\circ}, 9^{\circ}, 23$ e 25 da CADH.

É o que se passa a fazer, no âmbito dos diálogos jurisdicionais horizontais, ou seja, aqueles realizados a partir de uma exposição das diversas soluções que foram encontradas em âmbito local no contexto dos processos de impeachment.

Assim, este AC pretende colaborar ao ponto central da OC, a saber: como as garantias previstas na $\mathrm{CADH}$, especialmente procedimentais, podem assegurar que tais processos transcorram de modo a preservar o ambiente de legalidade democrática desenhado pelo SIDH.

\footnotetext{
56 A Corte ressaltou que a união do governo com o partido político liderado pelo ex-Presidente Bucaram demonstra indícios sobre os propósitos para afastar os magistrados da Corte Suprema e os membros do Tribunal Constitucional, tendo em vista a existência de um interesse em anular os julgamentos penais que foram levados a cabo pela Corte Suprema contra o ex-Presidente Bucaram e também contra o atual presidente. Destituir o Tribunal Constitucional, o Tribunal Eleitoral e a Corte Suprema, em 14 dias, parece inaceitável para a Corte. Todos esses atos geraram ainda mais instabilidade política e diversos movimentos se insurgiram contra o governo por entenderem que ele estava violando o Estado de Direito. Uma vez instalada, a nova Corte Suprema de Justiça adotou uma série de medidas de transcendência política, a exemplo da declaração de nulidade das ações contra o ex-presidente Bucaram. Na sequência, a Corte Suprema de Justiça foi destituída e o país permaneceu aproximadamente sete meses sem este órgão.

${ }^{57}$ Registre-se, por completude, que no precedente do Equador a Corte também condenou o Estado com base no artigo 24 da Convenção, por violação à igualdade perante a lei.
} 


\subsubsection{O impeachment no Paraguai}

\subsubsection{O tratamento constitucional do impeachment no Paraguai}

A Constituição paraguaia é de 1992. A previsão constitucional do impeachment está no artigo 225, o qual estabelece que:

El Presidente de la República, el Vicepresidente, los ministros del Poder Ejecutivo, los ministros de la Corte Suprema de Justicia, el Fiscal General del Estado, el Defensor del Pueblo, el Contralor General de la República, el Subcontralor y los integrantes del Tribunal Superior de Justicia Electoral, sólo podrán ser sometidos a juicio político por mal desempeño de sus funciones, por delitos cometidos en el ejercicio de sus cargos o por delitos comunes.

La acusación será formulada por la Cámara de Diputados, por mayoría de dos tercios. Corresponderá a la Cámara de Senadores, por mayoría absoluta de dos tercios, juzgar en juicio público a los acusados por la Cámara de Diputados y, en caso, declararlos culpables, al sólo efecto de separarlos de sus cargos, En los casos de supuesta comisión de delitos, se pasarán los antecedentes a la justicia ordinaria.

Como se pode perceber, a previsão constitucional é aberta, dando margem para que ocorra a responsabilização política pelo mau desempenho das funções presidenciais, além de delitos cometidos, sejam eles comuns ou políticos.

O processo de responsabilização consiste em formulação da denúncia pela Câmara dos Deputados, a qual deve ser aprovada com o quórum de $2 / 3$ dos deputados. O Senado julga com o mesmo quórum. Não há previsão de prazos para tal processo. Não foi encontrada nenhuma lei infraconstitucional que disciplinasse o processo de impeachment.

\subsubsection{2. $\quad$ Casos anteriores}

Anteriormente ao impeachment de Fernando Lugo em 2012, dois processos de impeachment foram levados a cabo no Paraguai; porém, nenhum deles resultou no afastamento do Presidente.

O primeiro caso se iniciou em 1998, contra o então Presidente Raúl Cubas Grau, logo após o atentado que matou o Vice-Presidente Luis María Argaña. No entanto, Cubas Grau renunciou antes mesmo do voto final do Congresso.

Raúl Cubas Grau foi acusado de mau desempenho de suas funções após ter desobedecido uma ordem de prisão contra o general Lino César Oviedo, condenado a dez anos de prisão por uma tentativa de golpe militar em 1996, contrariando o que fora decidido pela Suprema Corte paraguaia.

Os atores que levaram a cabo o processo de impeachment poderiam ser considerados como parte de uma elite no Congresso; no entanto, suas ações foram posteriormente apoiadas pela população nas ruas $^{58}$. Além disso, os conflitos internos na maior força política do país, o Partido Colorado, foram definitivos para o afastamento do Presidente em 1999.

\footnotetext{
${ }^{58}$ Leiv Marsteintredet. Presidential interruptons in Latin America: concepts, causes and outcomes. University of Bergen, 2009.
} 
Em cinco de dezembro de 2002 foi aberto um processo de impeachment na Câmara contra Luis González Macchi, em razão do mau uso de suas funções e corrupção; entre as denúncias contra o presidente figurava o desvio de cerca de dezesseis milhões de dólares de privatização de bancos.

Contudo, não foi atingido o quórum necessário no Senado para seu afastamento, já que dezoito dos quarenta e quatro senadores votaram “não” ao impeachment do presidente.

\subsubsection{Fatos ligados ao impeachment do presidente Fernando Lugo}

Fernando Lugo, da “Alianza Patriótica para el Cambio”, foi eleito em 2008, rompendo com a hegemonia de sessenta e dois anos do Partido Colorado no Paraguai. Lugo propôs pautas que culminaram com a diminuição de sua popularidade. No âmbito pessoal, o ex-bispo católico foi demandado em juízo para o reconhecimento de paternidade de supostos filhos. Além disso, houve baixo apoio parlamentar à sua posição quanto a conflitos referentes à terra, e que acabariam afetando interesses de elites oligárquicas. Entretanto o ponto culminante da queda de popularidade do Presidente foi o "caso Curuguaty”.

Nesta propriedade houve conflito entre policiais e “carperos" (movimento de campesinos sem-terra) em 15 de junho de 2012. Morreram dezessete pessoas: onze campesinos e seis policiais. O conflito fomentou a narrativa da insegurança e da tolerância do Presidente com grupos campesinos, considerados terroristas.

O processo contra Lugo foi célere. A denúncia foi apresentada em 21 de junho de 2012 e a destituição do Presidente foi votada no Senado no dia seguinte.

O libelo acusatório alegava cinco itens: (i) a ilegalidade do financiamento de encontro de jovens socialistas no comando de engenharia das forças armadas, ocorrido em 2009; (ii) o “caso Ñacunday”, a saber, que o governo teria financiado invasões de terra na região; (iii) insegurança crescente por suposta permissividade a "grupos terroristas"; (iv) a assinatura do Protocolo de Ushuaia II, considerado atentado à soberania do país; e (v) o já mencionado “caso Curuguaty”.

Os fatos foram imputados a Lugo por “inação e incompetência”. Segundo a denúncia, "todas as causas mencionadas acima são de notoriedade pública, motivo pelo qual não precisam ser provadas, conforme o ordenamento jurídico em vigor" ${ }^{59}$. No dia 21 de junho de 2012, a Câmara dos Deputados aceitou a acusação por setenta e seis votos favoráveis e um contrário, com três abstenções. Lugo teve menos de vinte e quatro horas para preparar sua defesa. Em 22 de junho, o processo no Senado tramitou durante aproximadamente cinco horas, havendo uma sessão extraordinária para a defesa, avaliação das provas, exame das provas e alegações e votação. O placar foi de trinta e nove senadores favoráveis e quatro contrários à destituição.

\footnotetext{
${ }^{59}$ Paraguay. Congreso Nacional. Cámara de Diputados. Libelo Acusatorio. Asunción, mimeo, 2012. Disponível em: $<$ https://goo.gl/U4S5Qd>.
} 


\subsubsection{4. caso no Judiciário}

Fernando Lugo propôs perante a Corte Suprema de Justiça ação de inconstitucionalidade da Resolução $\mathrm{n}^{\circ} 878^{60}$, para anular o julgamento da destituição sob alegação de violação do devido processo e do direito de defesa.

No dia 25 de junho a ação foi rejeitada liminarmente ${ }^{61}$ com o fundamento de que o processo de impeachment seria regido pelo art. 225 da Constituição, que, por sua vez, outorgava a competência para julgamento ao Congresso. Dessa forma, o processo teria natureza política e não jurisdicional. Assim, afirmou-se que as garantias processuais não seriam absolutas nessa modalidade de processo, além de que não haveria competência do Poder Judiciário para conhecer a questão.

Lugo propôs, então, uma segunda ação, que foi julgada em 20 de setembro de 2012. O fundamento da ação foi o de que a Resolução $n^{\circ} 881^{62}$ seria inconstitucional. A sentença da Corte Suprema de Justiça reafirmou o caráter político do processo e sua não justiciabilidade pelo fato de a competência ser do Congresso. Confira-se:

Por otra parte, el carácter "político" y no judicial del juicio político origina que en su realización no se apliquen las normas propias de un juicio realizado en sede judicial y que la forma y los plazos en que se desarrollará el mismo, puedan ser reglamentadas por los órganos encargados de su desarrollo. Por lo cual la acción de inconstitucionalidad debe ser rechazada ${ }^{63}$.

A sentença não enfrentou diretamente a alegação de que a aferição do mau desempenho da atividade de presidente poderia ser de caráter de aprovação ou reprovação subjetivo, entretanto considerou que a abertura do conceito de "mau desempenho" estabelece que seria competência do Congresso fazer juízo discricionário sobre seu enquadramento.

Quanto ao procedimento adotado, tampouco caberia à Corte posicionar-se, pois implicaria violação da competência do Congresso de estabelecer suas próprias normas.

\subsubsection{Respostas das instituições regionais}

A crise política no Paraguai teve respostas das instituições regionais durante e após o processo de impeachment. Nos dias anteriores à conclusão do processo houve manifestações da Unasul (União das Nações Sul-Americanas), com o envio de chanceleres para Assunção, e da OEA (Organização dos Estados Americanos), com a solicitação pelo Secretário-Geral de que fosse respeitado o "devido processo" ${ }^{64}$.

Após o impeachment, a Unasul e o Mercado Comum do Sul (Mercosul) suspenderam o Paraguai sob a aplicação da “cláusula democrática”. A previsão da cláusula democrática está nos dois Protocolos de Ushuaia sobre Democracia (1998 e 2011) no âmbito do Mercosul; no Protocolo Adicional sobre

\footnotetext{
${ }^{60}$ Trata-se da Resolução de 21 de junho de 2012, que estabeleceu o processo para a tramitação do juízo político previsto no artigo 225 da Constituição nacional paraguaia.

${ }^{61}$ Paraguay. Decisão liminar da ação de inconstitucionalidade 1533. Disponível em: <https://goo.gl/kZgni7> .

62 Trata-se da Resolução de 22 de junho de 2012, que "separou do cargo de presidente da república o cidadão Fernando Armindo Lugo Méndez”.

${ }^{63}$ Paraguay. Corte Suprema de la Justicia. Acordo y Sentencia no 1.323, p. 75-91. In: Gaceta Judicial. Ano 2013 , $n^{\circ} 3$. Disponível em: <https://goo.gl/dfKTKu>.

${ }^{64}$ Conforme divulgado pela própria OEA. Disponível em: <https://goo.gl/U4m2HK>.
} 
Democracia (2010) no âmbito da Unasul e na Carta Democrática Interamericana (2001) no âmbito da OEA.

Os documentos tratam de "ruptura ou ameaça de ruptura da ordem democrática” e "ameaça da ordem constitucional”, porém não definem especificamente quais seriam essas situações. Tanto a Unasul quanto o Mercosul consideraram que a o procedimento não respeitou o devido processo legal. $\mathrm{Na}$ decisão 26/12, de 29 de junho de $2012^{65}$, a Unasul considerou que houve ruptura da ordem democrática pelo procedimento sumaríssimo que evidenciou clara violação do direito ao devido processo, e, consequentemente, das mínimas garantias para defesa adequada. A suspensão das organizações foi revogada após a eleição de Horacio Cartes para a Presidência, em 2013.

O OEA enviou missão a Assunção, entre primeiro e três de julho de 2012, para verificar a situação no país, produzindo relatório ${ }^{66}$ sintetizando suas principais preocupações. O compromisso de que as eleições no ano seguinte (2013) seriam mantidas foi recebida com otimismo pela OEA.

Dessa maneira, tem-se hipótese em que as organizações regionais adotaram o entendimento de que o processo de responsabilização do presidente violou as suas garantias processuais, eximindo-se de manifestações mais diretas sobre o sentido e alcance de democracia no país.

\subsubsection{O caso Honduras: necessário distinguishing}

Embora a própria OC apresente o exemplo de Honduras como caso de julgamento político realizado de maneira irregular - a CIDH não hesita em qualificá-lo como "golpe de Estado" -, não parece que pode ser considerado um caso de julgamento político em sentido estrito, razão pela qual será tratado de forma apartada e mais minudente em seção posterior deste AC.

A comunidade internacional - incluindo os EUA, a União Europeia e a Assembleia Geral da ONU imediatamente condenou a destituição do presidente Zelaya ${ }^{67}$. A partir da invocação da Carta Democrática Interamericana, a Assembleia Geral da OEA denominou como golpe o fato ocorrido, em razão da "alteração inconstitucional da ordem democrática”, dando início ao processo de suspensão de participação de Honduras da $\mathrm{OEA}^{68}$. A OEA somente readmitiria a Honduras em junho de 2011, mais de um ano e meio após a eleição de Porfírio Lobo ${ }^{69}$.

As justificativas políticas hondurenhas não foram suficientes para esconder a maneira com que o Presidente foi destituído sem a sua oitiva ou procedimento prévio. A ausência de clara especificação constitucional a respeito de quem decide sua destituição - e, especialmente, sob quais bases procedimentais - contribuiu para deixar ainda mais manifesta a ofensa a preceitos básicos do devido processo legal $^{70}$.

Distintamente dos outros dois casos - Paraguai e Brasil -, a destituição do Presidente de Honduras e os eventos políticos que a circundaram foram examinados pelos órgãos componentes do SIDH.

\footnotetext{
${ }^{65}$ Confira-se: Unasur. Decisão no 26/12. Disponível em: <https://goo.gl/hetPc1>.

${ }^{66}$ Relatório da OEA. Disponível em: <https://goo.gl/Xqz5M5>.

${ }^{67}$ Albert Trithart. Democratic coups? Regional responses to the constitutional crises in Honduras and Niger. Journal of Public and International Affairs, Princeton, 2013, p. 112-133.

${ }^{68}$ Douglass Cassel. Honduras: Coup d'Etat in Constitutional Clothing? Scholarly Works, Paper 969, 2009.

${ }^{69}$ Albert Trithart, Democratic coups?, op. cit., p. 115.

${ }^{70}$ Douglass Cassel, Honduras: Coup d’Etat in Constitutional Clothing?, op. cit.
} 
No relatório de país feito sobre Honduras em 200971, intitulado "Honduras: derechos humanos y golpe de Estado", a CIDH expressou eloquentemente sua condenação aos eventos relacionados à destituição do presidente Zelaya, qualificando-os como golpe de Estado e apontando pela ilegitimidade do Estado de exceção implementado logo em seguida ${ }^{72}$.

Esse relatório teve como principal objetivo apresentar as violações de direitos humanos decorrentes do nominado golpe do Estado, sem se aprofundar propriamente quanto aos argumentos constitucionais, favoráveis ou contrários, relacionados à deposição de Zelaya. Todavia, sua reprovação da íntegra do processo de impeachment é evidente, desde a copiosa qualificação de golpe de Estado, até a declaração de ilegalidade do Estado de exceção e a maneira como as autoridades de fato estavam conduzindo investigações sobre denúncias de violações de direitos.

No caso "López Lone e outros Vs. Honduras"73, a Corte IDH expressamente afirma que a destituição de Zelaya constituiu fato ilícito internacional, a que se teria seguido a ilegitimidade internacional do governo de fato instalado. A Corte reverberou as diversas manifestações de outros órgãos internacionais, qualificando o evento como golpe de Estado ${ }^{74}$.

Aspecto crucial de diferenciação é que a Constituição de Honduras não previa sequer a possibilidade de impeachment ${ }^{75}$, como o fazem outras constituições do continente americano já referidas neste AC, como, por exemplo, as constituições do Paraguai e do Brasil.

Dessa forma, embora o caso hondurenho possa ser compreendido como um exemplo de golpe de Estado $^{76}$, dificilmente o caso Zelaya/Honduras pode ser enquadrado como um caso de julgamento político propriamente dito (impeachment).

Confundir o caso de Honduras com outros em que foi observado, em alguma medida mínima, o procedimento constitucionalmente estabelecido para destituição do chefe do Poder Executivo não favorece a elaboração de uma OC clara e pertinente pela Corte. Dessa forma, muito embora a CIDH tenha se referido a esse caso em sua OC, ele não deveria figurar como exemplo de "julgamento político".

\footnotetext{
71 OEA. Comissão Interamericana de Direitos Humanos. Honduras: Derechos Humanos y golpe de Estado. OEA/Ser.L/V/II. Doc. 55. 30 diciembre 2009.

72 OEA. Comissão Interamericana de Direitos Humanos. Honduras: Derechos Humanos y golpe de Estado. OEA/Ser.L/V/II. Doc. 55. 30 diciembre 2009, par. 7, 88 e 162.

${ }^{73}$ Corte IDH. Caso López Lone y otros Vs. Honduras. Excepción Preliminar, Fondo, Reparaciones y Costas. Sentencia de 5 de octubre de 2015. Serie C No. 302. Disponível em: <https://goo.gl/JjlJ7O>. Acesso em: 7 jan. 2018.

${ }^{74}$ Corte IDH, Caso López Lone y otros Vs. Honduras, op. cit., par. 152, 160, 174 e 229.

${ }^{75} \mathrm{O}$ dispositivo do impeachment foi revogado, de maneira um pouco confusa e equivocada, por emenda à Constituição hondurenha em 2003. Ver: Frank M. Walsh. The Honduran Constitution is not a suicide pact: the legality of Honduran President Manuel Zelaya’s removal. Georgia Journal of International and Comparative Law, V. 38. 2010 , p. 364. ${ }^{76}$ Como aponta Abbott Matthews (Perspectives on Instability: Honduras and Paraguay. Security and Defense Studies Review, V. 14, 2013, p. 144): “In Honduras, the process of removing Zelaya started when the National Congress and Supreme Court applied constitutional articles 304, 306, 313, and 373-374. These articles, as described before, gave the other institutions the capacity to remove Zelaya and invoke the armed forces to enforce the ruling. However, when the process was carried out within such a short time period and resulted in Zelaya's illegal exile, it was clear that the procedures had swerved into unconstitutional territory." Em sentido contrário, defendendo os fundamentos constitucionais para a destituição, ver Frank M. Walsh, The Honduran Constitution is not a suicide pact, op. cit.
} 
Fatos e argumentos extraídos do caso Zelaya somente serviriam para embaralhar os esclarecimentos relacionados ao "julgamento político" feito de maneira constitucional e - como pretende a OC - que observe garantias previstas na Convenção.

\subsubsection{O recente caso peruano}

O mais recente caso de juízo político envolvendo um presidente da república teve lugar no Peru, no segundo semestre de 2017. O procedimento teve início após a notícia de que o presidente Pedro Pablo Kuczynski teria recebido vantagens pecuniárias indevidas da empreiteira brasileira Odebrecht, cuja origem teria relação com supostas consultorias prestadas pelo político em período anterior ao pleito eleitoral de 2016. Os fatos se referiam a situações ocorridas entre os anos de 2001 e 2006, período em que o presidente ocupava o cargo de ministro de Estado no governo do então Presidente Alejandro Toledo. Kuczynski, que inicialmente negou ter recebido qualquer tipo de pagamento, reconheceu posteriormente que auferiu vantagens pecuniárias da empresa brasileira por meio de sua empresa Westfield Capital $\mathrm{Ltd}^{77}$.

Dentro da perspectiva da presente OC, debateu-se, no caso concreto, se o juízo político estaria a serviço da democracia ou contra ela. Em outras palavras, se o juízo político estava sendo exercido de forma válida. De um lado, trazia-se a alegação da incapacidade moral do Presidente, pela prática de supostos atos de corrupção; de outro, a sustentação de um possível golpe de Estado, com a violação da separação de Poderes e do sistema de freios e contrapesos.

No âmbito do Congresso peruano, unicameral, foi discutida de maneira fugaz a moção de vacância presidencial com base na alegada incapacidade moral de Kuczynski para exercer o cargo, a qual foi admitida em 17 de dezembro de 2017, após a obtenção do voto mínimo de 40\% de parlamentares previsto no artigo 89-A do Regimento Interno do Congresso Nacional.

Na oportunidade, Kuczynski enviou carta ao Secretário-Geral da Organização dos Estados Americanos, em que manifestou sua preocupação com os fatos e a estabilidade democrática de seu país, apontando violação à Carta Democrática Interamericana e solicitando, ainda, o envio de um observador externo para a sessão de debate.

Admitida a moção, a terceira num período de 100 anos no Peru, o julgamento foi designado para o dia 21 de dezembro de 2017. Nessa mesma ocasião facultou-se ao Presidente a realização de sua defesa, quer pessoalmente, quer por meio de advogado constituído.

Na véspera do início da votação, Kuczynski utilizou-se de estratégia de conteúdo político, promovendo a divulgação de mensagem à nação asseverando que caso fosse submetido ao afastamento, ocorreria de forma simultânea a renúncia dos cargos de vice-presidentes, ocupados por Martín Vizcarra e Mercedes Aráoz, de forma que a chefia do Executivo passaria para o Presidente do Congresso, que teria que convocar novas eleições gerais. Dessa forma, vinculou-se o destino do Presidente ao do próprio Congresso que o julgaria, uma vez que as novas eleições gerais abarcariam todos os cargos eletivos do Executivo e do Legislativo nacional. Diante desse novo panorama, até os congressistas mais favoráveis ao processo de afastamento do Presidente alteraram o seu posicionamento.

\footnotetext{
${ }^{77}$ É o que narra a moção.
} 
Iniciada a votação, a moção não foi aprovada face a ausência do quórum de 2/3 (87 votos) para se decretar a vacância presidencial, haja vista que foram contabilizados 79 (setenta e nove) votos a favor da moção, 19 (dezenove) votos desfavoráveis e 21 (vinte e uma) abstenções ${ }^{78}$.

Muito embora o procedimento realizado não se confunda propriamente com o processo de impeachment, previsto no artigo 117 da Constituição, este também configura, indubitavelmente, espécie de juízo político, cujo transcurso se deu inteiramente no âmbito do Poder Legislativo, regulado, inclusive, pelo Regimento Interno do Congresso Nacional.

Em conclusão, diante da brevidade com que o procedimento se desenvolveu, a questão atinente à preservação das garantias judiciais também aqui se coloca na dimensão do diálogo horizontal, ainda que o instituto em questão possua contornos peculiares face a outros tipos de juízos políticos.

\subsubsection{O caso brasileiro}

3.6.4.1. A medida cautelar na ADPF (Arguição de Descumprimento de Preceito Fundamental) $\mathrm{n}^{0} 378$ sobre o rito do processo de impeachment

O presente ponto trata da Arguição de Descumprimento de Preceito Fundamental (ADPF) proposta pelo Partido Comunista do Brasil com o objetivo de ter analisada pelo Supremo Tribunal Federal a compatibilidade entre o rito do impeachment do Chefe do Poder Executivo previsto e estipulado pela Lei $\mathrm{n}^{0}$ 1.079/1950, que define os crimes de responsabilidade e regula o respectivo processo de julgamento, e a Constituição da República de 1988.

A ADPF teve por objetivo a declaração de não recepção, bem como a interpretação conforme a Constituição, de diversos dispositivos da Lei $n^{0}$ 1.079/1950, a lei regente do procedimento de impeachment no Brasil. Segundo o autor, inúmeras previsões da Lei 1.079/1950 não foram recepcionadas pela sistemática constitucional pós-Carta de 1988, devendo haver compatibilização de disposições remanescente à Constituição de 1988, bem como o suprimento de lacunas na regulamentação respectiva. Pugnou, assim, por uma efetiva filtragem constitucional da Lei 1.079/1950.

O partido requerente sustentou, em suma, a necessidade de defesa prévia em todas as fases do processo; o afastamento da aplicação do Regimento Interno da Câmara e do Senado no rito delimitado pela Lei; o reconhecimento de que a defesa deve participar por último de todas as fases instrutórias; a incompatibilidade com a constituição vigente da previsão que permite à Câmara funcionar como tribunal de acusação; o reconhecimento de que o afastamento do Presidente só ocorre após a instauração do processo pelo Senado Federal; e que, durante o julgamento, os senadores não poderiam exercer, simultaneamente, a função acusatória e a julgadora.

Por fim, apresentou as razões para o deferimento do pedido liminar requerido. A Presidência da República, o Senado Federal e a Câmara dos Deputados prestaram informações, a Advocacia-Geral da União se manifestou e a Procuradoria-Geral da República deu parecer.

\footnotetext{
${ }^{78} \mathrm{O}$ fato foi amplamente noticiado na mídia local e internacional. Exemplificativamente, confira-se a notícia disponível em: <https://goo.gl/2zsS8e>.
} 
A cautelar incidental requerida pelo autor refere-se à forma de votação (aberta ou fechada) e ao tipo de candidatura (indicação pelo líder ou candidatura avulsa) dos membros da Comissão Especial junto à Câmara dos Deputados.

O partido requerente apresentou pedidos em medidas cautelares incidentais, especialmente no que se refere à forma de votação aberta na composição da Comissão Especial. O Ministro Relator Edson Fachin concedeu, com eficácia até a sessão plenária de 16 de dezembro daquele ano, o pedido liminar requerido e solicitou novas informações.

\subsection{O voto do Ministro Edson Fachin, relator originário}

O Ministro relator, Edson Fachin, dividiu seu voto em partes:

(i) Primeiramente, votou pelo conhecimento da mencionada ADPF, resumindo da seguinte forma suas razões para tanto: “(i) a jurisprudência desta Corte é pacífica sobre competir ao próprio STF o juízo sobre o que se deve compreender por preceito fundamental, mediante esforço hermenêutico que identifique 'as disposições essenciais para a preservação dos princípios basilares dos preceitos fundamentais de um determinado sistema' (ADPF - MC 33, Pleno, Rel. Min. Gilmar Medes, DJ 27.10.2006); (ii) na presente hipótese é possível inferir potencial ofensa, notadamente, ao sistema de governo, à separação de poderes, à soberania popular, ao direito ao devido processo legislativo e às garantias procedimentais no curso da apuração de crime de responsabilidade; (iii) ainda, está presente o requisito da subsidiariedade, pois 'a existência de processos ordinários e recursos extraordinários não deve excluir, a priori, a utilização da arguição de descumprimento de preceito fundamental, em virtude da feição marcadamente objetiva dessa ação’ (ADPF - MC 33, Pleno, Rel. Min. Gilmar Medes, DJ 27.10.2006); (iv) ao contrário do que se alega nas informações da Câmara dos Deputados, o objeto da presente arguição, como esclarecido no relatório, é a Lei 1.079/50, que dispõe sobre os crimes de responsabilidade, e foi promulgada sob a égide da Constituição da República de 1946. Trata-se, portanto, de um juízo de recepção sobre diploma legislativo anterior à ordem constitucional atual e não da suposta tentativa de julgamento de inconstitucionalidade dos regimentos internos das Casas do Congresso Nacional; (v) ainda, considero que as medidas cautelares incidentais que tratam da eleição da comissão especial guardam pertinência com a potencial recepção do art. 19 da Lei 1.079/50 pela Constituição da República de 1988, sobretudo no tocante à expressão 'comissão especial eleita'; (vi) ainda que assim não fosse, as noções de instrumentalidade das formas e de economia processual recomendam considerar as Petições/STF 64.212 e 64.216, ambas de 2015, como aditamento à peça inicial, tendo em vista a viabilidade do ajuizamento de uma nova arguição incidental ante a relevância da controvérsia constitucional em discussão; (vii) por fim, o tema referente ao impeachment presidencial é da mais alta magnitude jurídico-política, de maneira a revelar a imperatividade de um diálogo institucional entre o Supremo Tribunal Federal, na qualidade de guardião das regras da democracia constitucional, e os demais Poderes da República, aqui, por intermédio da prestação da jurisdição constitucional em processo objetivo”.

(ii) No segundo ponto, tratou do regime de responsabilidade do Presidente da República. Analisando a natureza jurídica do instituto do impeachment, o Ministro aduziu que: "(i) decorre do regime republicano e democrático a possibilidade de responsabilização do mandatário máximo da nação; (ii) é no preceito fundamental da relação entre os poderes que se deve buscar a natureza jurídica do impeachment, definido como um modo de se exercer o controle republicano do Poder Executivo; (iii) a exigência de lei específica, de um lado, e as garantias processuais, de outro, permitem configurá-lo como modalidade limitada de controle, na medida em que, sendo a República um fim comum, ambos os poderes devem a ele dirigir-se; (iv) o limite, por sua vez, decorre do fato 
de que não se pode, sob o pretexto de controle, desnaturar a separação de poderes; (v) não se pode identificar o instituto do impeachment, próprio dos regimes presidencialistas, com a moção de desconfiança, própria dos regimes parlamentaristas; (vi) o regime presidencialista, mais rígido do que o parlamentarista sobre as causas de responsabilização do Chefe do Poder Executivo, adota tipificação jurídico-política dos crimes de responsabilidade; (vii) ainda assim, é de natureza jurídicopolítica o julgamento constitucionalmente atribuído ao Parlamento; (viii) a opção constitucional por um sistema de governo presidencialista impõe que se interprete o instituto do impeachment tanto sob o prisma dos direitos e garantias individuais do ocupante de cargo público, quanto pela reserva de estrita legalidade, corolário para a harmoniosa relação entre os poderes; (ix) ao Supremo Tribunal Federal compete o controle da estrita legalidade procedimental do processo de impeachment, assegurando que o juízo jurídico-político de alçada do Parlamento, passível de controle judicial apenas e tão somente para amparar as garantias judiciais do contraditório e ampla defesa, se desenvolva dentro dos estritos limites do devido processo legal”.

(iii) Em terceiro tópico, tratou sobre a exigência de lei específica. Examinando a legislação, o Ministro novamente sintetizou o ponto trabalhado: "não há dúvida quanto à recepção dos aspectos materiais da Lei $\mathbf{n}^{0}$ 1.079/1950 pela Constituição de 1988; quanto aos seus aspectos processuais, no entanto, tendo em vista as modificações em relação ao papel da Câmara dos Deputados e do Senado Federal no processo de impeachment em relação às ordens jurídicas anteriores, é preciso realizar a sua leitura à luz dos mandamentos constitucionais; o sistema processual do impeachment está hoje previsto na imbricação entre a Constituição e a Lei $n^{0}$ 1.079/1950, que dão as linhas mestras e estruturantes a serem seguidas.”

(iv) Em quarto lugar, falou da filtragem constitucional da Lei $\mathbf{n}^{0}$ 1.079/1950 à luz da Constituição da República Federativa do Brasil de 1988 e da Convenção Americana de Direitos Humanos (Pacto de São José da Costa Rica). Aduziu o Relator que o STF não teria o papel de editar normatização acerca da matéria; sob o pálio da autocontenção, cogitar-se-ia apenas filtragem constitucional, ou seja, incidência plena da CRFB/1988 e exame da Lei 1.079/50 à luz de princípios e regras constitucionais vigentes. Arrematou asseverando que o procedimento de impeachment de Presidente da República deveria respeitar todas as garantias judiciais previstas no Pacto de São José da Costa Rica e na Constituição de 1988.

No que tange ao devido processo legal e processo de responsabilização jurídico-política, o relator afirmou que "se atribui ao processo mais do que a singela tarefa de servir como instrumento do provimento final, e assim deve ser compreendido, portanto, como meio de concretização dos ideais democráticos, cuja materialização passa, necessariamente, pelo desenvolvimento de procedimentos justos que observem as garantias constitucionais dos litigantes; e no caso, na sistemática questionada, há uma cisão quanto à responsabilização jurídico-política do Presidente da República. Vale dizer, a Câmara dos Deputados julga a admissibilidade da denúncia para fins de processamento e o Senado é encarregado do processo e julgamento do Presidente.”

Quanto à aplicação subsidiária dos Regimentos Internos da Câmara dos Deputados e do Senado Federal, o Ministro Fachin propôs o seguinte entendimento ao Plenário: “os Regimentos Internos da Câmara dos Deputados e do Senado Federal possuem aplicação no rito do impeachment naquilo que dizem respeito à auto-organização interna dos referidos órgãos legislativos, mas não para a autorização, processamento e julgamento do impeachment. Não há, assim, violação à reserva de lei exigida pelo art. 85 da Constituição de 1988." Concluiu, então, que se deveria adotar a técnica da “interpretação conforme” ao art. 38 da Lei 1.079/50. 
No que se refere ao recebimento da denúncia pela Câmara dos Deputados, entendeu que: “o recebimento operado pelo Presidente da Câmara configura juízo sumário da admissibilidade da denúncia para fins de deliberação colegiada, e não há obrigatoriedade de defesa prévia a essa decisão; como meio inerente ao contraditório, deve ser assegurado ao acusado a oportunidade de manifestação prévia à aprovação do parecer da Comissão Especial; no processo instaurado pela Câmara, se o juízo positivo não importar autorização de processamento do Presidente da República, trata-se de juízo de admissibilidade interno. Havendo autorização, a decisão resolve o mérito do processo instaurado na Câmara, com admissão do processamento no âmbito do Senado Federal. Adianto, desde logo, que a ausência de defesa prévia, nessa fase preambular, não viola o devido processo legal, razão pela qual indefiro o pedido cautelar 'a'."

No tocante ao procedimento de impeachment na Câmara dos Deputados, votou pela improcedência do pedido cautelar incidental do Autor que visava garantir que a votação no Plenário da Câmara dos Deputados para formação da Comissão Especial fosse aberta. Ainda, em relação ao pedido cautelar "c" da petição inicial, votou por declarar a recepção do art. 20, caput e $\S 1^{\circ}$, da Lei 1.079/50; dar interpretação conforme ao art. 20, § $2^{\circ}$, da Lei 1.079/50 a fim de firmar o entendimento de que antes da discussão única em plenário seja lida a manifestação do Presidente da República sobre o parecer preliminar elaborado pela Comissão Especial; declarar a recepção do art. 21, 22, caput, $\S 1^{\circ}$, $\S 2^{\circ}$, bem assim do art. 23, caput, da Lei 1.079/50; dar interpretação conforme ao art. 22, $\S 3^{\circ}$, a fim de firmar o entendimento de que o Presidente da República deveria ser notificado para apresentar alegações finais sobre o parecer definitivo da Comissão Especial.

Sobre o direito ao contraditório após parecer final e prévio à votação e necessidade de fundamentação da Comissão Especial à luz das hipóteses típicas, entendeu o Ministro que o contraditório, para além de uma garantia formal, com a contraposição entre hipóteses acusatória e defensiva, teria o condão de conferir caráter de legitimidade ao processo decisório. Também aduziu a exigibilidade de fundamentação da subsunção ao tipo jurídico-político do crime de responsabilidade imputado pela Comissão Especial. A indicação da tipicidade configuraria, assim, pressuposto da autorização de processamento.

No tocante ao procedimento de impeachment no Senado Federal, entendeu que, autorizada a instauração do processo contra o Presidente da República (art. 51, I, da CRFB/1988) ou, em outras palavras, admitida a acusação contra ele (art. 86, caput, da CRFB/1988), seria submetida a julgamento. A partir desse momento, teria início a tramitação do processo perante o Senado Federal. Neste ponto, o voto analisou os pedidos cautelares 'f', 'g', ' $h$ ' e 'j' da ADPF. Entendeu pela impossibilidade de juízo de admissibilidade pelo Senado Federal e a obrigatoriedade de processamento e julgamento. Conferindo ao art. 24 interpretação conforme, reconheceu apenas que a Câmara deveria enviar ao Senado a autorização para instauração de processo, e indeferiu os pedidos cautelares de itens ' $g$ ' e ' $h$ '. Segundo o Ministro, o Senado não detém competência para rejeitar autorização expedida pela Câmara dos Deputados, cabendo apenas a instauração do procedimento, por inexistir faculdade da Mesa do Senado quanto a isso, já que é claro o que define o art. 86 da Constituição: "admitida a acusação contra o Presidente da República, será ele submetido a julgamento". Rejeitou, também, o pedido cautelar 'j', entendendo que "tanto quanto as causas de impedimento e suspeição, outras limitações impostas aos magistrados, próprias do processo jurisdicional, que visam à garantia de um juízo dotado da mais absoluta imparcialidade, não se compatibilizam com o processo jurídico-político do impeachment”. Deferiu o pedido cautelar ' $\mathrm{f}$ ', dando interpretação conforme aos artigos 28 e 29 da Lei 1.079/50, fixando interpretação segundo a qual, a cada fase processual, a manifestação do acusado, pessoalmente ou por seus representantes 
legais, deveria ser o último ato de instrução, trazendo à baila novamente a fundamentação referente ao princípio do contraditório.

\subsection{O voto do Ministro Luís Roberto Barroso, redator do acórdão}

O Ministro Luís Roberto Barroso abriu a divergência e pautou seu voto, em suas próprias palavras, (i) na segurança jurídica, respeitando os precedentes do STF a respeito do impeachment produzidos durante o processo ocorrido em 1992 e (ii) nos ritos adotados pelo Congresso Nacional, com a chancela do Supremo, durante o procedimento de impeachment acontecido em 1992.

No terceiro ponto de seu voto, o Ministro Barroso dissertou sobre os "pontos de divergência” com o Relator, Ministro Fachin. Elencou três ordens de argumentos que justificariam o acolhimento de seus posicionamentos pelo Plenário: (i) razões de hermenêutica constitucional; (ii) razões de segurança jurídica consistentes na observância de posicionamentos emitidos anteriormente pela Corte; (iii) razões de observância à regra do jogo democrático.

Nesta primeira ordem de argumentação, de caráter hermenêutico, o Ministro Barroso se valeu, primeiramente, de um enfoque histórico, afirmando que a Constituição da República de 1988 traria uma inovação ao dispor diversamente das Constituições anteriores (1946, 1967 e 1969) a respeito da matéria. De acordo com o Ministro, a Constituição de 1988 designaria à Câmara dos Deputados apenas o papel de autorizar a instauração de processo pelo Senado. Percebe-se diferenciação, portanto, entre esta sistemática, na qual a Câmara teria papel de condicionar a procedibilidade para que a acusação prossiga no Senado, e os regimes constitucionais anteriores, nos quais a Câmara funcionaria como "tribunal de pronúncia". No aspecto literal, defendeu a possibilidade da compreensão da expressão "julgamento", presente no art. 86 da CRFB/1988, como abrangedora do processo como um todo, incluindo a fase do juízo preliminar sobre o recebimento da denúncia.

O Ministro Barroso discordou do Ministro Relator Edson Fachin, ainda, ao afirmar que admitir que a imprevisão no Regimento Interno do Senado Federal sobre o juízo de admissibilidade significaria a inexistência dessa fase procedimental resultaria em inverter a lógica da hierarquia das normas e subordinar a Constituição da República ao Regimento Interno do Senado. Baseado numa interpretação sistemática, o Ministro Barroso comparou a diminuição do papel do Senado Federal com a retirada de seu juízo preliminar à transformação da Casa num "simples balcão de protocolo".

Já no âmbito do argumento da segurança jurídica e da necessária observância de precedentes relevantes, ressaltou entendimento fixado quando do julgamento do Mandado de Segurança $n^{\circ}$ 21.564, ocasião na qual o Supremo Tribunal Federal julgou MS impetrado pelo então Presidente da República, Fernando Collor. O ministro ainda relembrou a grande repercussão da decisão após o Supremo ter decidido, em reunião administrativa, as regras do processo de impeachment do então Presidente Collor ${ }^{79}$.

No tocante à sua terceira ordem de argumentos, referente às razões de observância das regras do jogo, recordou que a própria Procuradoria-Geral da República emitiu manifestações divergentes por

\footnotetext{
79 "Pouco importa que tais decisões tenham sido proferidas há mais de vinte anos e por composição substancialmente distinta da Corte. O que está em jogo, afinal, é uma das matérias mais sensíveis à democracia e à separação de poderes no país, que, até mesmo por sua excepcionalidade, tende a ser objeto de poucas e espaçadas decisões pelo STF. Se tais decisões não forem levadas a sério como elemento conformador da atuação da Corte, a segurança jurídica, naturalmente reduzida em um processo político como o impeachment, ficará ainda mais esvaziada.”
} 
ocasião da ADPF 378 e do MS 21.564, sendo que entendeu que o Senado dispõe de competência para analisar a admissibilidade de denúncia que já fora autorizada pela Câmara. Isto seria, na visão do Ministro, uma demonstração do fato de que o posicionamento do STF à época fora incorporado ao ordenamento jurídico brasileiro, em certa medida, razão pela qual a alteração do entendimento da corte significaria uma ruptura normativa.

\subsection{Conclusão do julgamento sobre o rito do processo de impeachment}

O Plenário do Supremo Tribunal Federal, por maioria de oito a três, optou por seguir o entendimento, proposto pela divergência do Ministro Luís Roberto Barroso, de que o Senado Federal não está vinculado ao juízo autorizativo da Câmara dos Deputados. Em suma, no resultado final do julgamento da ADPF 378 decidiu-se: (a) que sendo apresentada denúncia contra o Presidente da República por crime de responsabilidade, cabe à Câmara a autorização para instauração de processo ${ }^{80}$, o que implica o exercício de um juízo político sobre os fatos apresentados. O Senado, por sua vez, tem o papel privativo de processar e julgar o Presidente, o que engloba um juízo inicial de instauração ou não do processo, isto é, a decisão sobre o recebimento da denúncia autorizada pela outra Casa. O entendimento foi fundamentado na impossibilidade de outra interpretação do texto constitucional, independentemente do enfoque dado, na segurança jurídica (considerando o caso do impeachment do Presidente Fernando Collor de Mello) e no fato se ser já um entendimento consolidado e incorporado à ordem jurídica brasileira. Com base nisso, o STF entendeu não terem sido recepcionados pela Constituição de 1988 os arts. 23, $\S \S 1^{\circ}, 4^{\circ}$ e $5^{\circ}$; 80, $1^{\text {a }}$ parte; e 81, todos da Lei 1.079/1950, porque incompatíveis com os arts. 51, I; 52, I; e 86, § $1^{\circ}$, II, todos da CF/1988; (b) em relação ao rito do impeachment na Câmara: o plenário deve deliberar apenas uma única vez, por maioria qualificada de seus integrantes, sem necessitar, porém, desincumbir-se de grande ônus probatório. O direito à ampla defesa do acusado é efetivado com a realização de dez sessões, tal como decidido no caso Collor; (c) em relação ao rito do impeachment no Senado: dada a inexistência de regras específicas acerca das etapas iniciais do rito no Senado, deve ser seguido o mesmo entendimento dado pelo STF quando do julgamento do caso Collor, consistente na aplicação das regras da Lei $\mathrm{n}^{0}$ 1.079/1950 relativas a denúncias por crime de responsabilidade contra Ministros do STF ou contra o PGR. Com isso, concluiu-se que a instauração do processo pelo Senado se dá por deliberação da maioria simples dos membros, partindo de parecer de Comissão Especial, sendo improcedentes o requerimento do autor da ADPF de (i) possibilitar à própria Mesa do Senado, por decisão irrecorrível, rejeitar sumariamente a denúncia; e (ii) aplicar o quórum de 2/3, exigível para o julgamento final pela Casa Legislativa, a esta etapa inicial do processamento; (d) que não é possível a apresentação de candidaturas ou chapas avulsas para formação da Comissão Especial (cautelar incidental), uma vez que incompatível com o art. 58, caput e $\S 1^{\circ}$, da CRFB/1988. Pedido procedente; (e) que a votação para formação da Comissão Especial somente pode se dar por voto aberto (cautelar incidental), em respeito aos princípios democrático, representativo e republicano, e também em respeito ao precedente firmado com o caso Collor. Pedido procedente; (f) que a defesa tem direito de se manifestar após a acusação (item 'e’ do pedido cautelar), em respeito à garantia constitucional do devido processo legal (due process of law). Pedido procedente.

Já por deliberações unânimes, também no mérito, decidiu-se: (a) que é impossível a aplicação subsidiária das hipóteses de impedimento e suspeição ao presidente da Câmara (item ' $\mathrm{k}$ ' do pedido cautelar). O art. 36 da Lei no 1.079/1950 já cuida da matéria ${ }^{81}$, não havendo necessidade da incidência

\footnotetext{
${ }^{80}$ Art. 51, I, da CF/1988.

81 “Art. 36. Não pode interferir, em nenhuma fase do processo de responsabilidade do Presidente da República ou dos Ministros de Estado, o deputado ou senador;
} 
subsidiária do Código de Processo Penal; (b) que não há direito à defesa prévia (item 'a’ do pedido cautelar), já que não consiste em exigência do princípio constitucional da ampla defesa, tampouco dos compromissos internacionais assumidos pelo Brasil, pois é, na verdade, uma exceção no processo penal. Ou seja, não há impedimento para que a primeira oportunidade de apresentação de defesa no processo penal comum se dê após o recebimento da denúncia. Pedido improcedente; (c) que a proporcionalidade na formação da Comissão Especial pode ser aferida em relação a blocos (item 'd' do pedido cautelar): o regime constitucional de 1988 estabeleceu a possibilidade de se assegurar a representatividade por bloco (art. 58, $\S 1^{\circ}$ ) e a delegação da matéria ao RI/CD (art. 58, caput). A aferição da proporcionalidade por bloco foi feita e tem sido aplicada reiteradamente pela Câmara na formação de suas Comissões e foi seguida no caso Collor. Pedido improcedente; (d) que os senadores não precisam se apartar da função acusatória (item 'j’ do pedido cautelar); (e) que é possível a aplicação subsidiária dos regimentos internos da Câmara e do Senado (item 'b’ do pedido cautelar), pois não viola a reserva de lei especial imposta pelo art. 85, parágrafo único, da Constituição, desde que as normas regimentais sejam compatíveis com os preceitos legais e constitucionais pertinentes, limitando-se a disciplinar questões interna corporis. Pedido foi considerado improcedente; (f) que o interrogatório, instrumento de autodefesa que densifica as garantias do contraditório e da ampla defesa, deve ser o ato final da instrução probatória (item ' $\mathrm{f}$ ' do pedido cautelar), numa aplicação analógica da interpretação dada pelo STF ao rito das ações penais originárias. Pedido considerado procedente.

Assim, conforme acórdão, foi conhecida a ação por unanimidade de votos e rejeitadas as preliminares, nos termos do voto do Relator, Min. Edson Fachin. A atuação judicial é restringida, no caso do impeachment, à garantia do devido processo legal no rito, especialmente no que se refere à observância aos direitos e garantias do acusado (legalidade, contraditório e ampla defesa), previstos na CADH. O papel do STF em tal julgamento é, portanto, o de conferir harmonia ao rito para com as regras e os princípios constitucionais, zelando pelo respeito ao previsto na Constituição da República e na CADH.

\subsubsection{O processo de impeachment na Câmara dos Deputados}

Na Denúncia por Crime de Responsabilidade 1/2015, apresentada por Hélio Pereira Bicudo, Miguel Reale Júnior e Janaína Conceição Paschoal, em desfavor da então Presidente da República, Dilma Rousseff, autuada no dia dois de dezembro de 2015, afirmou-se, em síntese:

(a) que o Brasil está "mergulhado em profunda crise” política “e, sobretudo”, MORAL” (f. 02); (b) há um "quadro de horror"; (c) a existência de instituições que "estão funcionando bem", e por isso os crimes podem ser desvendados; (d) há suspeitas sobre as contas da campanha da então Presidente; (e) o Tribunal de Contas da União "assinalou flagrantes violações à Lei de Responsabilidade Fiscal” (f. 03); (f) a então Presidente "deixou de contabilizar empréstimos tomados de Instituições Financeiras públicas (Caixa Econômica Federal e Banco do Brasil), contrariando, a um só tempo, a proibição de fazer referidos empréstimos e o dever de transparência quanto à situação financeira do país. Em suma, houve uma maquiagem deliberadamente orientada a passar para a nação (e também aos investidores internacionais) a sensação de que o Brasil estaria economicamente saudável e, portanto, teria condições de manter os programas em favor das classes mais vulneráveis"; (g) o Tribunal de Contas da União "rejeitou as contas do Governo Dilma, relativamente a 2014”; (i) alega a violação do art. 9, itens 3 e 7, da Lei 1.079/1950 (crimes contra probidade - "não tornar efetiva a responsabilidade dos

a) que tiver parentesco consangüíneo ou afim, com o acusado, em linha reta; em linha colateral, os irmãos cunhados, enquanto durar o cunhado, e os primos co-irmãos;

b) que, como testemunha do processo tiver deposto de ciência própria.” 
seus subordinados, quando manifesta em delitos funcionais ou na prática de atos contrários à Constituição”; "proceder de modo incompatível com a dignidade, a honra e o decoro do cargo)”; (j) maquiagem das contas públicas (coloquialmente chamada de "pedaladas fiscais").

No tocante aos crimes de responsabilidade praticados contra a Lei Orçamentária, especificamente contra as normas que regem a abertura de créditos suplementares, alegaram:

(a) a edição de decretos para abertura de créditos suplementares sem autorização do Congresso Nacional (art. 10, itens 4 e 6, Lei 1.079/1950), no valor de R\$18.448.483.379,00 (mais de dezoito bilhões de reais); (b) que o Governo Federal não estava cumprindo as metas da Lei de Diretrizes Orçamentárias - o resultado primário; (c) que a então Presidente conhecia do desrespeito à meta e não contingenciou gastos; (d) que os fatos ocorreram em 2014 e 2015; (e) que as Leis Orçamentárias de 2014 e 2015 previam que a "abertura de créditos suplementares" somente ocorreria se fosse "compatível com a obtenção da meta de resultado primário"; (f) que a "infringência às leis orçamentárias é patente, contumaz e reiterada”.

Quanto aos crimes de responsabilidade pelas “desinformações contábeis e fiscais” - vulgo “pedaladas fiscais”, disseram:

(a) que "a contabilidade da União não espelha a realidade das contas públicas - o que afronta a necessária transparência” (f. 22); (b) que houve violação ao art. 11, itens 2 e 3 da Lei 1.079/1950, bem como do art. 85 da Constituição Federal; (c) "a União realizou operações de crédito ilegais a partir do não repasse de recursos a entidades do sistema financeiro nacional controladas pela própria União" (f. 24); (d) que houve desrespeito ao art. 29, III, da Lei de Responsabilidade Fiscal, bem como do art. 36 (que "proíbe a realização de operações de crédito entre uma instituição financeira estatal e o ente da federação que a controla, na qualidade de beneficiário do empréstimo"; (e) os bancos oficiais surgiam como apenas "operadores do programa, não como agente financiador".

Ainda, houve acusação do "não registro de valores no rol de passivos da dívida líquida do setor público”, crime previsto no art. $9^{\circ}$ da Lei 1.079/1950. A alegação foi:

afronta à Lei Orçamentária Anual - LOA, na medida em que impede o efetivo acompanhamento das contas de Governo, pois parte expressiva do passivo deixa de ser registrada, com o que o acompanhamento das metas de superávit primário passa a ser uma ficção (f. 36).

Pediram, ao final, a perda do mandato da Presidente e inabilitação para exercer cargo público por oito anos (art. 52, parágrafo único, Constituição).

Na sessão do dia três de dezembro de 2015, a denúncia foi lida perante a Câmara dos Deputados. Em seguida, o Presidente da Câmara dos Deputados, Eduardo Cunha, resolveu constituir Comissão Especial, “destinada a dar parecer sobre a denúncia contra a Senhora Presidente da República”, com a seguinte composição: “composta por 65 (sessenta e cinco) Deputados titulares e igual número de suplentes a serem eleitos pelo Plenário, de acordo com a seguinte proporção: PMDB 8 (oito); PP 4 (quatro); PTB 3 (três); Democratas 2 (dois); PRB 2 (dois); SD 2 (dois); PSC 2 (dois); PHS 1 (um); PTN 1 (um); PMN 1 (um); PEN 1 (um); PT 8 (oito); PSD 4 (quatro); PR 4 (quatro); PROS 2 (dois); PCdoB 1 (um); PSDB 6 (seis); PSB 4 (quatro); PPS 1 (um); PV 1 (um); PDT 2 (dois); PSOL 1 (um); PTC 1 (um); PTdoB 1 (um); PMB 1 (um); e Rede 1 (um)”. E, então, aprovou-se a notificação à Presidente. 
Em 17 de abril de 2016, em sessão deliberativa extraordinária, a Câmara dos Deputados autorizou a instauração de processo por crime de responsabilidade, por "abertura de créditos suplementares por decreto presidencial, sem autorização do Congresso Nacional (Constituição Federal art. 85, VI, e art. 167, V; e Lei n 1.079, de 1950, art. 10, item 4, e art. 11, item 2); e da contratação ilegal de operações de crédito (Lei n. 1.079, de 1950, art. 11, item 3)”82.

Após a votação pela admissibilidade da denúncia pela Câmara dos Deputados, o processo tramitou ao Senado Federal, recebendo, novamente, parecer.

\subsubsection{O Mandado de Segurança $n^{\circ} 34.130$}

O presente tópico objetiva analisar o pedido de Medida Cautelar em Mandado de Segurança 34.130/DF ${ }^{83}$, impetrado contra atos realizados no curso do processo de impeachment da então Presidente Dilma Roussef, expondo as discussões do Plenário do Supremo Tribunal Federal, especialmente em relação ao devido processo legal, ao contraditório e à ampla defesa (art. $5^{\circ}$, LIV e LV da Constituição de $1988^{84}$ ).

É pertinente destacar que o mandado de segurança é remédio constitucional, previsto no ordenamento jurídico brasileiro para, segundo o art. $5^{\circ}$ LXIX da Constituição de 1988, "proteger direito líquido e certo, não amparado por habeas corpus ou habeas data, quando o responsável pela ilegalidade ou abuso de poder for autoridade pública ou agente de pessoa jurídica no exercício de atribuições do Poder Público". Ademais, o mandado de segurança não admite dilação probatória, de forma que as provas e documentos essenciais devem acompanhar a petição inicial. Além disso, é possível o requerimento de medida liminar em sede de mandado de segurança, a qual será concedida se presente o fumus boni iuris, ou seja, a probabilidade do direito, a verossimilhança das alegações e o periculum in mora, isto é, o perigo da demora, o receio de que a demora da decisão judicial cause um dano de grave ou difícil reparação.

${ }^{82} \mathrm{O}$ inteiro teor encontra-se disponível em: <https://goo.gl/yJJWGj>.

83 O julgado possui a seguinte ementa: "MANDADO DE SEGURANÇA. MEDIDA LIMINAR. DIREITO CONSTITUCIONAL. CONTROLE DE ATOS DA CÂMARA DOS DEPUTADOS NO RITO DO PROCESSO DE IMPEACHMENT DE PRESIDENTE DA REPÚBLICA. GARANTIA DO DEVIDO PROCESSO LEGAL. DEVER DE APRECIAÇÃO DA DENÚNCIA ORIGINALMENTE APRESENTADA. MEDIDA LIMINAR INDEFERIDA. 1. No julgamento da ADPF 378, Rel. Min. Edson Fachin, Redator para o Acórdão o Min. Luís Roberto Barroso, DJe 18.12.2015, o Tribunal assentou que no rito do processo de Impeachment cabe à Câmara dos Deputados autorizar ou não a instauração do processo contra o Presidente da República nos crime de responsabilidade e ao Senado Federal compete o recebimento, pronúncia e julgamento da denúncia, devendo o presente writ ser examinado à luz da Constituição, da Lei 1.079/1950 e, especialmente, do que esta Corte decidiu na ADPF 378. 2. Tratando-se de mera condição de procedibilidade para a instauração do processo de Impeachment, inexiste fumus boni iuris quanto às alegações de ofensa à ampla defesa e ao contraditório, consubstanciadas na ausência de notificação da denunciada sobre a realização de esclarecimentos acerca da denúncia e posterior indeferimento de pedido de reabertura de prazo para a manifestação da defesa, juntada de documento estranho ao objeto da denúncia e ausência de manifestação do Procurador da impetrante na sessão de leitura do relatório na Comissão Especial. Isso porque, nessa fase ainda não há acusado ou litigante. 3. A autorização advinda da votação havida na Comissão Especial da Câmara dos Deputados é para o prosseguimento sob o teor da denúncia, escoimando-se, para o efeito de apreciação ulterior em Plenário, o que for estranho ao ‘vero e proprio’ teor primeiro da denúncia. 4. Medida liminar indeferida (MS 34130 MC, Relator(a): Min. EDSON FACHIN, Tribunal Pleno, julgado em 14/04/2016, PROCESSO ELETRÔNICO DJe-185 DIVULG 31-08-2016 PUBLIC 01-09-2016).”

84 “Art. $5^{\circ}$ Todos são iguais perante a lei, sem distinção de qualquer natureza, garantindo-se aos brasileiros e aos estrangeiros residentes no País a inviolabilidade do direito à vida, à liberdade, à igualdade, à segurança e à propriedade, nos termos seguintes:

LIV - ninguém será privado da liberdade ou de seus bens sem o devido processo legal;

LV - aos litigantes, em processo judicial ou administrativo, e aos acusados em geral são assegurados o contraditório e ampla defesa, com os meios e recursos a ela inerentes;” 
O caso em análise, trata-se de mandado de segurança com pedido liminar impetrado pela Presidente da República, Dilma Rousseff, representada pelo Advogado-Geral da União, José Eduardo Martins Cardozo, em face dos atos praticados pelo presidente da Câmara dos Deputados no exercício das suas competências e do Presidente e Relator da Comissão Especial que aprovou o parecer pela admissibilidade da apuração da Denúncia por Crime de Responsabilidade de $n^{\circ} 01 / 2015$. O processo foi autuado em 14/04/2016, sendo a liminar indeferida em 15/04/2016 e o acórdão publicado em 01/09/2016.

O Mandado de Segurança sustenta, em síntese: a) a competência do STF para realização de controle dos atos da Câmara dos Deputados no processo de impeachment que atentem contra normas constitucionais e procedimentais; b) não se tratar de ato interna corporis da Câmara dos Deputados, inexistindo ofensa à separação dos Poderes; c) que se aplicaria ao processo de impeachment as garantias fundamentais que viabilizam o exercício da ampla defesa, estando incluída a necessidade de imputações claras, objetivas e circunscritas ao objeto, sem ampliação posterior ou ao longo do processo.

Quanto ao mérito, a inicial afirma diversas violações a macular os atos realizados nos autos da Denúncia por Crime de Responsabilidade de $n^{\circ}$ 01/2015: a) aduz que os limites da denúncia foram extrapolados nos debates e discussões realizados perante a Comissão Especial, levando à inviabilização da defesa, diante da constante mudança em relação aos fatos imputados; b) salienta que, no plano de trabalhos da Comissão, foi determinada a realização de "esclarecimentos" sobre a denúncia, sem que a Presidente tenha sido notificada do ato, do qual decorreu ampliação dos fatos supostamente ensejadores da prática de crime de responsabilidade; c) sustenta que, na sessão em que ocorreram os "esclarecimentos”, houve extrapolação dos termos da denúncia, sendo tratados aspectos alheios aos trabalhos da Comissão, inviabilizando a construção de uma defesa materialmente hábil, devido à mutatio emprestada às imputações; d) alude que foi juntado aos autos do processo, que tramita na Comissão Especial, documento absolutamente estranho ao objeto da denúncia, a saber, a colaboração premiada realizada em processo penal pelo Senador Delcídio do Amaral, em que pese a total desconexão dos fatos ali narrados com o objeto da denúncia; e) argumenta que foi indeferido o pedido de reabertura de prazo para a defesa diante da colheita dos "esclarecimentos" acerca da denúncia apresentada e acolhida, o que impossibilitou o direito de defesa proporcional ao que efetivamente vem sendo imputado; f) diz que, em confronto com a legislação de regência, foi indeferido ao defensor constituído pela presidente, na sessão em que se realizou a leitura do relatório produzido pelo Deputado Jovair Arantes, o direito à voz; g) afirma que foram indicadas, no parecer elaborado pelo relator da Comissão Especial, diversas imputações e considerações de cunho persuasivo, totalmente desconectadas do teor da denúncia, em flagrante e inconstitucional ampliação das imputações das quais a Presidente foi intimada para se defender, o que inviabilizaria a construção de uma defesa substancialmente adequada; h) salienta que foi aprovado pela Comissão Especial parecer elaborado pelo Deputado Jovair Arantes, maculado por todos os vícios acima narrados, dentre outros; i) aduz que foi determinada pela Mesa da Câmara dos Deputados a leitura em Plenário e a publicação da íntegra do parecer no Diário da Câmara dos Deputados, novo ato praticado subsequentemente às nulidades apontadas e eivado por elas.

Por fim, requer a concessão da liminar, para que o Presidente da Câmara dos Deputados, sua Mesa Diretora e qualquer de seus órgãos se abstenham de levar ao Plenário a deliberação referente à Denúncia por Crime de Responsabilidade de $n^{0} 1 / 2015$ até que sanadas todas as alegadas violações ou até a apreciação do Mandado de Segurança pelo Plenário do STF. No mérito, requer a nulidade de todos os atos do processo de Denúncia por Crime de Responsabilidade de $n^{0} 1 / 2015$ posteriores à decisão do Presidente da Câmara dos Deputados que permitiu a juntada aos autos do Termo de 
Colaboração Premiada do Senador Delcídio do Amaral. Subsidiariamente, requer: a) o reconhecimento da nulidade do Parecer e de sua leitura em Plenário, com a consequente b) determinação de elaboração de novo Parecer nos estritos limites da denúncia originalmente recebida pelo Presidente da Câmara dos Deputados; c) o desentranhamento dos autos de todos os termos de colaboração premiada de qualquer pessoa, bem como de qualquer documento estranho às matérias recebidas pelo Presidente da Câmara dos Deputados; d) o reconhecimento da nulidade da realização da sessão de oitiva dos denunciantes ocorrida em 30/03/2016 e o desentranhamento de quaisquer atos com ela relacionados; e) caso reconhecida a validade desta última, seja reaberto o prazo de 10 (dez) sessões para a apresentação da defesa.

O Ministro Edson Fachin, como relator do caso, foi o primeiro a proferir seu voto. Nele destaca que, em relação ao alcance do direito ao contraditório e à ampla defesa no processo de impeachment, votou anteriormente na ADPF 378 no sentido de que os mesmos implicam: a) realizar uma interpretação conforme ao art. $20, \S 2^{\circ}$, da Lei $1.079 / 50^{85}$, com o objetivo de firmar o entendimento de que antes da discussão em plenário seja lida a manifestação do Presidente da República sobre o parecer preliminar elaborado pela Comissão Especial; b) declarar a recepção do art. 22, caput, da Lei $1.079 / 50^{86}$ para que, no caso de o plenário decidir que a denúncia deve ser objeto de deliberação, o Presidente da República seja notificado para contestar a denúncia, indicando meios de prova; c) realizar interpretação conforme ao art. 22, $\S 3^{\circ},{ }^{87}$ da Lei 1.079/50 para firmar o entendimento de que a oportunidade de contradizer o parecer final da Comissão Especial configura meio inerente ao contraditório. Afirma ainda que salientou em seu voto anterior na ADPF 378 que a indicação da tipicidade é pressuposto da autorização de processamento, na medida de responsabilização do Presidente da República nas hipóteses prévia e taxativamente estabelecidas. Sustenta que, em seu voto anterior, defendeu que, em relação ao art. 23, § $1^{\circ}$, da Lei 1.079/50 $0^{88}$, deve-se dar interpretação conforme a constituição vigente para inferir que à expressão "decretada a acusação", constante no art. 59, I, da Constituição de $1946^{89}$, deve ser dirigida uma interpretação evolutiva, à luz do art. 51, I, da Constituição de $1988^{90}$, de forma que deve-se fixar interpretação constitucional ao $\S 1^{\circ}$ do art. 23 da Lei, no sentido de que o efeito lógico da procedência da denúncia na Câmara dos Deputados é a

\footnotetext{
85 “Art. 20. [...] § $2^{\circ}$ Quarenta e oito horas após a publicação oficial do parecer da Comissão especial, será o mesmo incluído, em primeiro lugar, na ordem do dia da Câmara dos Deputados, para uma discussão única.”

86 “Art. 22. Encerrada a discussão do parecer, e submetido o mesmo a votação nominal, será a denúncia, com os documentos que a instruam, arquivada, se não for considerada objeto de deliberação. No caso contrário, será remetida por cópia autêntica ao denunciado, que terá o prazo de vinte dias para contestá-la e indicar os meios de prova com que pretenda demonstrar a verdade do alegado.”

87 “Art. $22[\ldots] \S 3^{\circ}$ Publicado e distribuído esse parecer na forma do $\S 1^{\circ}$ do art. 20, será o mesmo, incluído na ordem do dia da sessão imediata para ser submetido a duas discussões, com o interregno de 48 horas entre uma e outra.”

88 “Art. 23. [...] § $1^{\circ}$ Se da aprovação do parecer resultar a procedência da denúncia, considerar-se-á decretada a acusação pela Câmara dos Deputados.”

89 “Art. 59 - Compete privativamente à Câmara dos Deputados: I - a declaração, pelo voto da maioria absoluta dos seus membros, da procedência ou improcedência da acusação, contra o Presidente da República, nos termos do art. 88, e contra os Ministros de Estado, nos crimes conexos com os do Presidente da República.”

90 “Art. 51. Compete privativamente à Câmara dos Deputados: I - autorizar, por dois terços de seus membros, a instauração de processo contra o Presidente e o Vice-Presidente da República e os Ministros de Estado.”
} 
autorização para processar o Presidente da República por crime de responsabilidade, de forma que deve ser declarada a não recepção dos artigos 23, § 5 ${ }^{091}$; 80, caput ${ }^{92}$, ab initio; e $81^{93}$ da Lei 1.079/50.

Em seu voto, o Ministro Fachin salienta que, apesar das suas ponderações no julgamento da ADPF 378, o Plenário do STF decidiu conforme o voto de divergência do Ministro Luís Roberto Barroso (voto vencedor). Conta que o Ministro Barroso aduziu em suas razões que o papel da Câmara é o de mera autorização de recebimento da acusação, tendo o Senado o papel de recebimento da denúncia, decisão de pronúncia e de condenação, de forma que, na Câmara, há uma única votação por 2/3 sobre a admissão, ou não, autorização, ou não, da acusação, e que, no Senado, há três votações: por maioria simples, para receber a denúncia; por maioria simples, para a pronúncia; e por maioria de 2/3, para a condenação.

Em continuidade, após expor as razões do voto vencedor do Ministro Barroso na ADPF, o Ministro Fachin salienta que mantém a mesma convicção de seu voto anterior, mas que, em face do princípio da colegialidade, os pedidos do Mandado de Segurança devem ser analisados sob a perspectiva do voto vencedor do Ministro Barroso na ADPF 378.

Após tal explicação, dando continuidade ao voto, o Ministro Fachin aduz que, relativamente (a) à extrapolação da denúncia nos debates e discussões perante a Comissão Especial, (b) à ausência de notificação da denunciada sobre a realização de esclarecimentos sobre a denúncia e (c) à total extrapolação dos termos da denúncia, o que se está debatendo é a admissibilidade para a autorização do processamento e julgamento de impeachment. Nesse aspecto, o Ministro Fachin alude que o ônus probatório durante a tramitação do pedido de impeachment na Câmara dos Deputados deve ser conforme o voto vencedor do Ministro Barroso na ADPF 378. Sustenta que, conforme aduziu o Ministro Barroso, o rito do impeachment perante a Câmara, previsto na Lei $n^{\circ} 1.079 / 50$, teve sua sistemática em parte revogada pela Constituição de 1988, que alterou o papel institucional da Câmara no impeachment do Presidente da República. Para o Ministro Fachin, conforme voto vencedor do Ministro Barroso, o Plenário da Câmara deve deliberar uma única vez, por maioria qualificada de seus integrantes, sem necessitar, porém, desincumbir-se de grande ônus probatório, pois cabe à Câmara apenas autorizar ou não a instauração do processo. Segundo o Ministro Fachin, de acordo com o voto vencedor do Ministro Barroso, não podem ser tidos como recepcionados pela Constituição de 1988 preceitos legais que atribuem à Câmara dos Deputados funções excedentes do papel de instauração de processo contra o Presidente. Assim, nos termos do voto de Barroso, devem ser considerados como recepcionados pela Constituição de 1988 os arts. 20 e 21 da Lei no 1.079/50 ${ }^{94}$,

\footnotetext{
91 “Art. 23 [...] § 5 5 São efeitos imediatos ao decreto da acusação do Presidente da República, ou de Ministro de Estado, a suspensão do exercício das funções do acusado e da metade do subsídio ou do vencimento, até sentença final.”

92 “Art. 80. Nos crimes de responsabilidade do Presidente da República e dos Ministros de Estado, a Câmara dos Deputados é tribunal de pronuncia e o Senado Federal, tribunal de julgamento; nos crimes de responsabilidade dos Ministros do Supremo Tribunal Federal e do Procurador Geral da República, o Senado Federal é, simultaneamente, tribunal de pronuncia e julgamento.”

93 “Art. 81 A declaração de procedência da acusação nos crimes de responsabilidade só poderá ser decretada pela maioria absoluta da Câmara que a preferir.”

94 “Art. 20. A comissão a que alude o artigo anterior se reunirá dentro de 48 horas e, depois de eleger seu Presidente e relator, emitirá parecer, dentro do prazo de dez dias, sobre se a denúncia deve ser ou não julgada objeto de deliberação. Dentro desse período poderá a comissão proceder às diligências que julgar necessárias ao esclarecimento da denúncia. $\S 1^{\circ} \mathrm{O}$ parecer da comissão especial será lido no expediente da sessão da Câmara dos Deputados e publicado integralmente no Diário do Congresso Nacional e em avulsos, juntamente com a denúncia, devendo as publicações ser distribuídas a todos os deputados.

$\S 2^{\circ}$ Quarenta e oito horas após a publicação oficial do parecer da Comissão especial, será o mesmo incluído, em primeiro lugar, na ordem do dia da Câmara dos Deputados, para uma discussão única.
} 
desde que interpretados conforme a Constituição, para que se entenda que as "diligências" referidas no art. 20 não se destinam a provar a (im)procedência da acusação, mas apenas a esclarecer a denúncia.

O voto do Ministro Fachin assevera que, como se infere da leitura do voto vencedor do Ministro Barroso na ADPF 378, não se deveria admitir como ofensa ao direito ao contraditório os esclarecimentos propostos pela Comissão Especial, pois as diligências referidas no art. 20 não se destinam a provar a (im)procedência da acusação, mas sim a esclarecer a denúncia.

O Ministro Fachin registra que, por ocasião dos debates realizados no julgamento da ADPF 378, destacou uma preocupação em relação à consequência do rito que a divergência do Ministro Barroso propunha. Explica que tal preocupação com o rito mais abreviado na Câmara seria porque o direito de a Presidente se defender seria bastante abreviado. Aponta o Ministro Fachin que, durante as discussões, propôs que na Comissão Especial fossem garantidas três manifestações: logo após o parecer preliminar; depois da primeira discussão única no Plenário da Câmara, que admite a denúncia como objeto de deliberação, vinte dias para contestar; e um conjunto de razões finais após o parecer final da Comissão. O Ministro Fachin ainda destaca que, nas discussões do julgamento da ADPF 378, o Ministro Barroso propôs que o rito na Câmara fosse exatamente o mesmo adotado para o impeachment do Collor, o qual teve dez sessões para a defesa estabelecidas pelo STF, salientando o ministro que aquilo que se perde em ritualística na Câmara transferiu-se, por força da Constituição, para o Senado. Nesse quadro, o Ministro Fachin aduz ainda que, pela leitura dos debates que integram o acórdão da ADPF 378, não há a rigor nem litigante, nem acusado. Diante de todo o exposto, o Ministro Fachin conclui que, no mandado de segurança em análise, o que a Presidente objetiva é fazer prevalecer a tese que restou vencida no julgamento da ADPF 378, o que não tem cabimento.

Quanto à (d) juntada de documento estranho ao objeto da denúncia, notadamente, a colaboração premiada realizada pelo Senador Delcídio do Amaral, o Ministro Fachin sustenta que tal elemento foi considerado como irrelevante para o relatório final da Comissão Especial. Argumenta ainda que, se é no Senado que o contraditório deverá ser amplamente exercido, deve ser no Senado que a pertinência do documento com a denúncia deve ser avaliada.

Com relação ao (e) indeferimento do pedido de reabertura de prazo para a defesa depois dos esclarecimentos prestados, o Ministro Fachin assevera que não assiste sorte à Presidente, pois nos termos do voto vencedor na ADPF 378, não se está a promover acusação, mas mera discussão sobre possível juízo de autorização para a instauração de processo de impeachment, de forma que as diligências devem ser entendidas como sendo aquelas tendentes a esclarecer a denúncia. O Ministro Fachin registra, ainda, que, conforme Requerimento $n^{\circ}$ 24/2016, a Comissão Especial convidou a Presidente a participar da fase de esclarecimentos.

O Ministro Fachin vota ainda no sentido de que a (f) falta de manifestação do procurador da Presidente na sessão de leitura do Relatório não constitui cerceamento de defesa porque tal momento é de competência exclusiva dos Deputados membros da Comissão. No que se refere (g) às diversas imputações e considerações supostamente desconectadas do teor da denúncia como originalmente formulada, Fachin afirma que, como o que se apreciará no Plenário é mesmo teor inicial, não se sustenta a alegação de inviabilização de defesa adequada, pois a impetrante se manifestou sobre tais imputações no dia 04/04/2016, após o encerramento da fase de esclarecimentos.

Art. 21. Cinco representantes de cada partido poderão falar, durante uma hora, sobre o parecer, ressalvado ao relator da comissão especial o direito de responder a cada um.” 
Após tais fundamentações, Fachin conclui seu voto no sentido de que, tomando como baliza o voto vencedor na ADPF 378, não constatados os vícios alegados, não há que se falar em nulidade do Parecer ou em necessidade de renovação de quaisquer dos atos já praticados. Assenta que a autorização advinda da votação havida na Comissão Especial é para o prosseguimento sob o teor da denúncia original, escoimando-se, para apreciação ulterior em plenário da Câmara dos Deputados, o que for estranho ao primeiro teor da denúncia. Por fim, conclui pela não concessão da liminar, pela ausência de fumus boni iuris.

Depois de o Ministro Fachin proferir seu voto como Relator, o Advogado-Geral da União propôs questão de ordem, solicitando que pudesse realizar sustentação oral. Fundamentou seu pedido no sentido de que se interpretasse o Código de Processo Civil de maneira conjugada com a Lei que disciplina o mandado de segurança, para se entender pela possibilidade de, em casos como esse, em que pudesse haver a perda do objeto do mandado de segurança pela não concessão da medida liminar, se deferisse ao advogado a possibilidade de sustentação oral.

Quanto ao pedido, o Relator Ministro Fachin, afirmou que, como possivelmente se encontravam na última sessão que precederia a circunstância fática a que o Mandado de Segurança se referia, votava no sentido de deferir a sustentação oral. Após, foi aberto o debate quanto à possibilidade de sustentação oral. O Ministro Ricardo Lewandowski acompanhou o Ministro Fachin, alegando que estavam diante de uma situação excepcional, pois qualquer decisão a ser tomada pela Câmara dos Deputados teria um enorme impacto político, social e econômico. Aludiu que mesmo que depois a Corte revisse o entendimento num julgamento de mérito do mandado de segurança, os prejuízos seriam irreparáveis. Afirmou que, em homenagem ao princípio da ampla defesa, seria adequado ouvir o Advogado-Geral da União.

Em manifestação quanto à possiblidade de sustentação, o Ministro Gilmar Mendes afirmou a inconsistência do argumento do Advogado-Geral da União, aduzindo que, se fosse indeferida a liminar, o mandado de segurança prosseguiria e se poderia anular a decisão da Câmara. No mesmo sentido, o Ministro Celso de Mello afirmou ser inviável a postulação do Advogado-Geral da União, salientando que, mesmo que indeferida a cautelar, o writ mandamental poderia vir a ser concedido, com a invalidação da deliberação questionada.

Ainda quanto à questão, o Ministro Marco Aurélio salientou que a extensão do pedido, em termos de liminar, não define o direito ou não à sustentação na tribuna. Já o Ministro Barroso afirmou que não concordava com a colocação de uma exceção para que o Advogado-Geral da União sustentasse, votando pela impossibilidade de sustentação. O Ministro Barroso foi acompanhado pelos Ministros Teori Zavascki, Cármen Lúcia, Gilmar Mendes e Marco Aurélio. Os argumentos trazidos foram, entre outros, a necessidade de se resguardar a isonomia. O Ministro Celso de Mello também indeferiu o pedido de sustentação oral, alegando que, não obstante a vigência do novo Código de Processo Civil, ainda continuaria a subsistir a inadmissibilidade da sustentação oral em certas causas, como nos pleitos de medida cautelar.

Assim, o Plenário do STF decidiu, por maioria, indeferir o requerimento do Advogado-Geral da União de realizar sustentação oral, vencidos os Ministros Edson Fachin e Ricardo Lewandowski, que acolheram o pedido.

Voto subsequente foi o do Ministro Luís Roberto Barroso, para o qual, em síntese, há as seguintes impugnações por parte da Presidente da República: 1) a de que o Parecer iria além do objeto da denúncia, nos termos em que ela foi efetivamente recebida; 2) as violações à ampla defesa e ao 
contraditório. Alude que, tal como o Ministro Fachin, pensa que a deliberação que será feita pela Câmara será nos termos da denúncia. Aduz que acha que o parecer diz muitas coisas além, mas, concretamente, fora o que seja obiter dicta ou contextualização, trata das duas imputações demarcadas pela denúncia.

Em manifestação sobre o voto do Ministro Barroso, o Ministro Fachin alude que a pretensão da impetração é fazer um controle judicial do conteúdo do parecer, o que não acolhe. Em resposta, Barroso afirma que interpretou o que está no parecer, que não sejam as questões da denúncia, como obter dicta e não propriamente matéria a ser objeto de deliberação. Aduz que, no tocante às violações à ampla defesa e ao contraditório, restou assentado que essa fase na Câmara ainda era uma fase préprocessual; portanto, uma analogia mais próxima a um inquérito do que a um processo já judicializado. Argumenta que a ampla defesa e o contraditório mais minuciosos serão exercidos eventualmente no Senado. Diz que considerara que a deliberação na Câmara fosse um juízo preliminar político de mera autorização. Argumenta que se é equiparável ao inquérito, é uma fase em que o contraditório é mitigado. Quanto à queixa de não ter podido responder a tempo e à hora algumas impugnações, inclusive fora do âmbito da denúncia, diz que não se aplica aqui, por decisão do Supremo, um contraditório detalhado e minucioso.

Após o voto do Ministro Barroso, o Ministro Lewandowski requereu um esclarecimento em relação ao art. 218, parágrafo $8^{\circ}$, da Resolução da Câmara dos Deputados $n^{0} 22$, de $1992^{95}$. Afirmou que entendeu que tanto o Ministro Fachin como o Ministro Barroso estavam sustentando que o que seria considerado era a denúncia em seus dois aspectos, e não o parecer. O Ministro Fachin, em resposta, afirmou que tentou explicitar no seu voto que a orientação majoritária na ADPF 378, contra seu voto, dos do Ministro Gilmar e do Ministro Toffoli, formou-se no sentido de delimitar essa fase como meramente autorizativa, transferindo ao Senado um papel de relevo. Disse que a conclusão a que chegara era apenas a de inferir coerência com o voto majoritário. Aduziu que a interpretação que o Ministro Lewandowski estava a dar e esse dispositivo sucumbia diante do que prevaleceu majoritariamente no Plenário. Em réplica, o Ministro Lewandowski aludiu que também entendeu que a Corte decidira na ADPF 378 que essa era uma fase de mera delibação na Câmara dos Deputados. Todavia, salientou que estava entendendo que seria uma certa demasia colocar-se em votação em Plenário uma imputação que atribuía à Presidente fatos anteriores aos mandatos, ou fatos anteriores, inclusive, ao momento em que ela foi eleita pela primeira vez. Questionou se a Câmara teria a amplitude de deliberar sobre qualquer assunto que extrapolasse a denúncia. Em contra-argumentação, Fachin afirmou que o recebimento da denúncia a delimitara, de forma que quando se referia à denúncia original, estava se referindo à denúncia e ao recebimento, o qual está sob autoridade da Presidência da Câmara.

O Ministro Teori Zavascki votou no sentido de acompanhar o Relator. Em seu Voto, aduziu não ver os requisitos para a concessão da liminar no Mandado de Segurança. Sustentou que as alegações da Presidente poderiam ser divididas em dois grandes blocos. Disse que um bloco seria referente à questão relacionada com o excesso, em que o Mandado de Segurança não deixaria claro se era excesso na deliberação da Comissão, afirmando que houve excesso nos debates feitos na Comissão, que teriam ido além do objeto da denúncia. O Ministro continuou afirmando que se alegava também que se juntaram documentos estranhos ao objeto e que o objeto deveria ser a denúncia nos termos e limites em que foi recebida. Aludiu que o Ministro Fachin resolvera isso muito claramente, assim como o Ministro Barroso, sendo esse o primeiro bloco de alegações. Disse que o segundo bloco de alegações

95 “Art. 218. [...] § $8^{\circ}$ Encerrada a discussão do parecer, será o mesmo submetido à votação nominal, pelo processo de chamada dos Deputados.” 
dizia respeito a possíveis danos ao contraditório e à ampla defesa. Aludiu que nesse ponto o Ministro Fachin deixou pontuado que o procedimento no âmbito da Comissão, como definido no julgamento da ADPF 378, seria um procedimento da admissibilidade da acusação. Salientou que acrescentaria que sempre é necessário que se demonstre efetivo prejuízo decorrente da alegada nulidade por cerceamento de defesa. Argumentou que as várias oportunidades que a defesa teve de se manifestar no processo espancaram eventuais deficiências pontuais que poderiam ter havido. Disse que não viu no Mandado de Segurança demonstração de prejuízo efetivo por eventuais inconsistências que poderiam ter havido em relação ao contraditório e ao direito de defesa, notadamente no que se refere à falta de oportunidade para se manifestar sobre os esclarecimentos adicionais.

Posteriormente, a Ministra Rosa Weber proferiu seu voto. Nele afirmou que depreendeu que o Ministro Fachin partia do princípio de que a denúncia havia de ser apreciada nos exatos limites em que fora recebida. Aludiu que, ao fazer a leitura da inicial do Mandado de Segurança, viu que nela se alegava que a denúncia apresentava uma terceira imputação, mas que fora recebida apenas quanto a duas imputações. Aduziu que lhe parecia que por isso o Advogado-Geral da União veio defender a tese da preclusão, pois no momento oportuno não teria sido manejado o recurso previsto no regimento interno da Câmara. Sustentou que, partindo do pressuposto de que estavam tratando da denúncia nos limites em que foi recebida, acompanhava integralmente o voto de Fachin no sentido de que também não se poderia alegar cerceamento de defesa em função do quanto decidido no exame da ADPF 378.

Já o Ministro Luiz Fux, em seu voto, destacou que na ADPF 378 o STF estabeleceu esse rito, concedendo à Câmara apenas o poder de autorizar o encaminhamento do processo ao Senado Federal. Aludiu que a questão do julgamento ultra, extra ou citra petita seria uma questão que se daria no âmbito do Senado Federal, porque o próprio STF decidira que a atuação da Câmara seria a de apenas autorizar o encaminhamento do processo para o Senado Federal. Sustentou que os Ministros Fachin e Barroso deixaram claro que o parecer se adstringiria exatamente a esses dois fatos relativos à denúncia. Aduziu que assistia também razão ao Ministro Teori no sentido de que, nessa fase, não havia nenhum prejuízo e a lei seria clara no sentido de que não se decreta nenhuma nulidade quando não há prejuízo, por força do princípio da instrumentalidade das formas.

Após, a Ministra Cármen Lúcia apresentou seu voto no sentido de acompanhar o Relator, chamando a atenção para a circunstância que foi por ele enfatizada de que, nos documentos juntados no Mandado de Segurança, haveria pelo menos em algumas passagens a cópia do parecer e, em mais de uma ocasião, havia sido feita referência a eventos que diziam respeito a período anterior. Aludiu que não poderiam ser incluídos fatos e atos supostamente praticados, mas que não diziam respeito ao atual mandato. Disse que o que seria objeto da denúncia é o que havia sido objeto do parecer, no que precisava ser então submetido rigorosa e estritamente.

O Ministro Gilmar Mendes, em seu voto, acompanhou integralmente o Relator.

Já o Ministro Marco Aurélio, em seu voto, aduziu que a liminar deveria ser concedida em algum sentido. Aludiu que todos os colegas estavam de acordo em assentar que, no caso, a Presidente seria julgada segundo os termos da denúncia e não os do parecer, no qual houve a junção de fatos estranhos à denúncia. Disse que, na parte não admitida, não houve recurso para o Plenário, como previsto no Regimento Interno da Câmara.

O Ministro Marco Aurélio aduziu que havia pedido um aparte ao Ministro Barroso após ele ter consignado o rito da Câmara na ADPF 378. Disse que questionou o Ministro Barroso no sentido de que, a rigor, levando em conta cláusula constitucional, ainda não se teria, no âmbito da Câmara, nem 
acusado nem litigante. Após a explicação, levantou a questão sobre se poderiam cogitar do que proclamara o Ministro Barroso (dez sessões para defesa), pois ainda não se tinha a qualificação de acusado na Câmara, embora existente denúncia a encerrar imputações. Aludiu que, a seu ver, não poderiam.

Ainda, o Ministro disse que havia entendido que os fatos articulados na inicial do Mandado de Segurança haviam sido comprovados. Aduziu que no Mandado de Segurança se apontara haver algo que praticamente teria impedido o exercício do direito de defesa. Aludiu que, voltando à Lei $\mathrm{n}^{\circ}$ 1.079/50, reconhecia que havia uma razão de ser na existência do parecer. Disse que ele ganharia contornos e até verdadeira pronúncia, tendo sido lido em sessão como redigido. Admitiu que o Tribunal apontara que não se teria no processo da Câmara duas fases: haveria a fase prévia, na qual não haveria direto de defesa, que desaguaria, a teor do disposto na Lei $n^{0} 1.079 / 50$, em uma deliberação para se assentar se, no caso, a denúncia seria objeto ou não de deliberação, sendo que, observada essa primeira fase, voltaria o processo à comissão para instrução, o que pressuporia a audição da envolvida e emissão de um novo parecer quanto ao que seria, segundo a Lei ${ }^{\circ} 1.079 / 50$, a procedência, ou não, da imputação e a continuidade do processo de impedimento. Acreditava que, considerado até o próprio sistema, haveria fase de audição da interessada e outra, como está na lei, de verdadeira instrução. Disse que, segundo o $\S 1^{\circ}$ do artigo $22^{96}$ da Lei ${ }^{\circ} 1.079 / 50$, findo o prazo e com ou sem contestação da acusada, a Comissão Especial deveria determinar as diligências requeridas por quem denunciou e também pela denunciada ou o que julgasse conveniente, e realizaria as sessões necessárias para a tomada de depoimento das testemunhas de ambas as partes. Aduziu que, a menos que se declarasse que esse artigo 22 da Lei $n^{0}$ 1.079/50 era inconstitucional, haveria de observar-se, admitida a fase única para parecer, o devido processo legal e o contraditório.

O Ministro Marco Aurélio argumentou também em seu voto que haveria de haver pelo consenso da maioria o deferimento de alguma liminar, porque, caso contrário, a deliberação na Câmara consideraria, em última análise, o parecer que foi lido em Plenário. Aludiu que não havia dúvida de que os deputados levariam em conta a peça da Comissão Especial tal como se continha. Argumentou que se o STF concluísse que a denúncia balizava a apreciação do colegiado, deveria sinalizar nesse sentido, e a única forma de fazê-lo com eficácia seria implementando uma liminar. Afirmou que o artigo 22 da Lei $\mathrm{n}^{\circ}$ 1.079/50 havia sido recepcionado pela Carta de 1988. Questionou o que seria objeto da deliberação, se a imputação contida na denúncia recebida ou as imputações contidas no parecer da Comissão Especial. Aludiu que o consenso seria no sentido de ser a denúncia, tal como recebida pelo presidente da Casa. Salientou ainda que ficara vencido quando disse que, tendo a deliberação do Senado tamanha repercussão a implicar o afastamento da Presidente da República por

\footnotetext{
96 “Art. 22. Encerrada a discussão do parecer, e submetido o mesmo a votação nominal, será a denúncia, com os documentos que a instruam, arquivada, se não fôr considerada objeto de deliberação. No caso contrário, será remetida por cópia autêntica ao denunciado, que terá o prazo de vinte dias para contestá-la e indicar os meios de prova com que pretenda demonstrar a verdade do alegado.

$\S 1^{\circ}$ Findo esse prazo e com ou sem a contestação, a comissão especial determinará as diligências requeridas, ou que julgar convenientes, e realizará as sessões necessárias para a tomada do depoimento das testemunhas de ambas as partes, podendo ouvir o denunciante e o denunciado, que poderá assistir pessoalmente, ou por seu procurador, a todas as audiências e diligências realizadas pela comissão, interrogando e contestando as testemunhas e requerendo a reinquirição ou acareação das mesmas.

$\S 2^{\circ}$ Findas essas diligências, a comissão especial proferirá, no prazo de dez dias, parecer sobre a procedência ou improcedência da denúncia.

$\S 3^{\circ}$ Publicado e distribuído esse parecer na forma do $\S 1^{\circ}$ do art. 20, será o mesmo, incluído na ordem do dia da sessão imediata para ser submetido a duas discussões, com o interregno de 48 horas entre uma e outra.

$\S 4^{\circ}$ Nas discussões do parecer sobre a procedência ou improcedência da denúncia, cada representante de partido poderá falar uma só vez e durante uma hora, ficando as questões de ordem subordinadas ao disposto no $\S 2^{\circ}$ do art. 20.”
} 
180 dias, essa medida deveria pressupor votação pela maioria qualificada, de 2/3. Disse que o Tribunal apontara que não, que a deliberação do Senado poderia se fazer por maioria simples. Constatou que o processo na Câmara, no qual se exige 2/3 para ter-se como autorizada a acusação, seria da maior valia, pois abriria a porta para um crivo do Senado, a ocorrer por maioria simples. Questionou se não caberia limitar a acusação àquilo constante da denúncia.

Ainda, o Ministro Marco Aurélio aludiu que o parecer extravasaria os limites da denúncia. Aduziu que a Presidente se defendera tal como constante na denúncia e não no parecer da Comissão Especial. Argumentou que se o Supremo se silenciasse quanto a essa questão haveria a consideração do parecer na extensão existente, objeto de leitura para ciência dos que votariam.

Em manifestação o Ministro Lewandowski aludiu que essa era uma preocupação sua porque segundo o art. $218 \S 8^{\circ}$, da Resolução da Câmara dos Deputados ${ }^{\circ}$ 22, de $1992^{97}$ o parecer é que seria submetido à votação e todos teriam afirmado que deveria haver uma correspondência entre ele e a denúncia.

Em continuidade, o Ministro Marco Aurélio argumentou que, como a Presidente havia se defendido da denúncia, não se defendera após a leitura do parecer no Plenário, de forma que a deliberação do Colegiado maior teria de considerar estritamente a denúncia e não o parecer, que a extravasara. Afirmou que acolhia, em um primeiro plano, as preliminares de nulidade. Disse que haveria de haver o implemento de liminar, para que não houvesse dúvidas de que a deliberação do Plenário da Câmara de Deputados ficaria estrita ao que se continha na denúncia admitida, não podendo o colegiado levar em conta fatos diversos, não constantes na denúncia.

Em seu voto, o Ministro Celso de Mello acompanhou o Ministro Relator Edson Fachin, indeferindo a postulação cautelar.

Por fim, em seu voto, o Ministro Lewandowski disse que concordava com o Ministro Marco Aurélio no que dizia respeito à necessidade de implementar uma cautelar, tendo em vista a conclusão a que chegou o plenário no sentido de que a denúncia deveria cingir-se apenas àquelas duas acusações que haviam sido recebidas pelo Presidente da Câmara. Disse que havia entendido que o procedimento na Câmara seria um procedimento que levaria a um mero juízo de admissibilidade, um juízo, segundo a ADPF 378, precário, porque poderia ser alterado pelo Senado, de maneira que as nulidades arguidas na impetração deveriam ser examinadas com certa relativização. Disse que não chegava a ponto de assentar que tinha havido nulidade por cerceamento de defesa. Aduziu que o Plenário da Câmara havia entendido, por ampla maioria, que não teria havido nulidade insanável. Aludiu que os denunciantes haviam sido ouvidos e a denunciada não. Argumentou que teria havido um prejuízo, o qual havia se materializado no sentido do extravasamento do parecer em relação àquilo que se continha na denúncia. Insistindo no art. 218, § 8 ${ }^{\circ}$, da Resolução da Câmara dos Deputados ${ }^{\circ}$ 22, de 1992, que diz que o parecer é que será submetido à votação nominal por parte da Câmara dos Deputados, afirmou que acolhia o pedido alternativo formulado na impetração da alínea "c", no sentido de que houvesse o devido desentranhamento, dos autos da Denúncia por Crime de Responsabilidade $\mathrm{n}^{\mathrm{o}} 1$ de 2015, de todos os documentos relativos a colaborações premiadas de qualquer pessoa, bem como de qualquer documento que fosse estranho às matérias recebidas pelo Presidente da Câmara dos Deputados. Concluiu que, se o § $8^{\circ}$ do art. 218 da Resolução da Câmara dos Deputados n 22, de 1992 estabelecia que o parecer é que seria votado, e se o parecer trouxesse

97 “Art. 218. [...] § $8^{\circ}$ Encerrada a discussão do parecer, será o mesmo submetido a votação nominal, pelo processo de chamada dos Deputados.” 
uma série de matérias extravagantes, poderia induzir a erro os nobres parlamentares. Votou pela implementação parcial da medida liminar, para que fosse expungido do parecer tudo aquilo que não constava da denúncia recebida pelo Presidente da Câmara dos Deputados e, em consequência, para que nada daquilo que constava da denúncia, se eventualmente aceita pela Câmara dos Deputados, pudesse ser apreciado pelo Senado Federal.

Diante desse quadro, os Ministros do Supremo Tribunal Federal, decidiram, por maioria e nos termos do voto do Relator Ministro Edson Fachin, indeferir o pedido de medida liminar e firmar o entendimento no sentido de que: “[...] a autorização advinda da votação havida na comissão especial é para o prosseguimento sob o teor da denúncia original, escoimando-se, para o efeito de apreciação ulterior em plenário da Câmara dos Deputados, o que for estranho ao teor 'vero e próprio' do teor primeiro da denúncia”. Foram vencidos os Ministros Marco Aurélio e Ricardo Lewandowski. No fim do julgamento, submetida a questão ao Plenário, os Ministros autorizaram que fosse consignado em ata que o objeto de deliberação pela Câmara estaria restrito à denúncia recebida pelo Presidente daquela Casa, ou seja i) "seis Decretos assinados pela denunciada no exercício financeiro de 2015 em desacordo com a LDO e, portanto, sem autorização do Congresso Nacional” e ii) "reiteração da prática das chamadas pedaladas fiscais”.

\subsubsection{4. $\quad$ O processo de impeachment no Senado}

\subsection{Da admissibilidade da denúncia perante o Senado Federal}

Afirmou o relatório que o defeito da conduta da então Presidente Dilma Vana Rousseff havia sido a forma como conduziu a política fiscal, "mediante o uso irresponsável de instrumentos orçamentáriofinanceiros”. Assim, para "tipificar” a conduta, decidiu-se que houve:

(a) “Ofensa aos art. 85, VI e art. 167, V da Constituição Federal, e aos art. 10, item 4, e art. 11, item 2 da Lei ${ }^{\circ} 1.079$ de 1950, pela abertura de créditos suplementares sem autorização do Congresso Nacional”.

(b) "Ofensa aos art. 85, VI e art. 11, item 3 da Lei ${ }^{0} 1.079$, de 1950, pela contratação ilegal de operações de crédito com instituição financeira controlada pela União”.

Admitiu-se a denúncia, instaurando-se o processo de impeachment.

3.6.4.5. Do parecer da Junta Pericial designada no âmbito da Comissão Especial do Impeachment 2016 - Senado Federal

Seguindo para o parecer da Junta Pericial, entendeu-se que:

(a) sobre os decretos de crédito suplementar:

1. A estrita redação do art. $4^{\circ}$ da LOA/2015 não faz menção à compatibilidade entre os Decretos e a programação financeira, mas entre aqueles e a programação orçamentária. Os institutos, embora correlacionados, não se confundem. Exemplo disso é o pagamento de restos a pagar e a restituição de recursos de terceiros, que têm reflexos na programação financeira, mas não na orçamentária.

2. Nesse cenário, dos quatro Decretos não numerados ora em análise, que abriram crédito suplementar, três deles promoveram alterações na programação orçamentária incompatíveis com a obtenção da meta de resultado primário vigente à época da edição dos Decretos. São eles: os Decretos 
de 27 de julho de 2015, nos valores de $R \$$ 1.701.389.028,00 e R\$29.922.832,00; e o Decreto de 20 de agosto de 2015, no valor de $R \$ 600.268 .845,00$.

3. Como esses decretos não se subsumem as condicionantes expressas no caput do art. $4^{\circ}$ da LOA/2015, sua abertura demandaria autorização legislativa prévia, nos termos do art. 167, inciso V, da $C F / 88$.

4. No momento da edição dos Decretos, a meta vigente era aquela originalmente constante da LDO/2015. Contudo, a meta considerada à época, inclusive para fins de definição $e$ operacionalização das limitações de empenho e movimentação financeira, foi a constante do PLN 5/2015, que só foi convertido na Lei $n^{\circ}$ 13.199/2015 em 3 de dezembro de 2015.

5. Embora não se tenha obtido informações completas relativas à execução das dotações suplementares constantes exclusivamente desses três Decretos (excluídas as dotações iniciais e demais suplementações), esta Junta identificou que pelo menos uma programação de cada decreto foi executada orçamentária e financeiramente no exercício financeiro de 2015, com consequências fiscais negativas sobre o resultado primário apurado.

6. Há efeitos negativos sobre a obtenção da meta resultado primário decorrentes da utilização do superávit financeiro do exercício anterior e do excesso de arrecadação como fontes para suplementação de despesas primárias.

No caso do superávit financeiro, os recursos constituem receita orçamentária de exercício anterior, não sendo computados como nova receita orçamentária no exercício em que se abre o crédito suplementar. A consequência é geração de uma despesa primária não compensada por uma arrecadação de receita primária ou cancelamento de uma despesa primária de montante equivalente. No que tange ao excesso de arrecadação de receitas primárias, essas constituem receita primária do exercício e têm efeito positivo sobre o resultado primário. Assim, em uma situação de não cumprimento da meta, tal como a relatada nos diversos Relatórios de Avaliação de Receitas e Despesas Primárias editados pelo Poder Executivo ao longo do exercício de 2015, esse excesso de arrecadação deve ser utilizado para a recomposição do resultado fiscal projetado, objetivando o atingimento da meta vigente na época considerada.

7. Segundo as informações apresentadas pela SOF (DOC 121 e seus anexos), nos processos de formalização dos Decretos não houve alerta de incompatibilidade com a meta fiscal.

8. Há ato comissivo da Exma. Sra. Presidente da República na edição dos Decretos, sem controvérsia sobre sua autoria ${ }^{98}$.

(b) sobre as operações com bancos oficiais:

1. As subvenções concedidas no âmbito do Plano Safra têm previsão legal (Lei $n^{\circ}$ 8.427/1992), e a despesa executada em 2015 tinha previsão orçamentária da LOA/2015. As subvenções são pagas ao Banco do Brasil pelo Tesouro Nacional por equalização de taxas e os beneficiários são os tomadores de crédito rural contratado junto à instituição financeira. Os pagamentos dessas subvenções são regulados por portarias do Ministério da Fazenda.

2. Houve operações de crédito do Tesouro Nacional junto ao Banco do Brasil, conforme as normas contábeis vigentes, em decorrência dos atrasos de pagamento das subvenções concedidas no âmbito do Plano Safra. Em 31 de dezembro de 2014, o valor devido pelo Tesouro ao Banco do Brasil era de $R \$$ 9,51 bilhões, e, em 15 de dezembro de 2015, de R\$10,65 bilhões (DOC 132).

${ }^{98}$ Brasil. Senado Federal. Parecer da Junta Pericial designada no âmbito da Comissão Especial do Impeachment 2016. Disponível em: <https://goo.gl/FETkhZ>. Acesso em: jan. 2018. 
3. A despeito do comando do art. 50, inciso II, da LRF, os passivos - subvenções e operações de crédito - não eram, historicamente, registrados pelo Tesouro Nacional o que passou a ocorrer a partir de 31 de dezembro de 2015 (DOC 132). Em contrapartida, o Banco do Brasil registrava os valores devidos pelo Tesouro Nacional em seu balanço patrimonial em conta do ativo não captada pelas estatísticas fiscais elaboradas pelo Banco Central.

4. A atualização da subvenção devida é calculada com base nas taxas SELIC e da caderneta de poupança. Tais taxas remuneram o credor, em lugar de apenas manterem o poder aquisitivo dos montantes devidos. Desse modo, tal atualização constitui verdadeira correção da subvenção devida.

5. Em decorrência de atrasos do pagamento, o montante acumulado, em 31 de dezembro de 2014, a título de correção ("atualização") do principal devido era de $R \$ 1$,05 bilhão (DOC 132). Em 2015, o valor efetivamente pago a esse título foi de $R \$ 1,13$ bilhão (Tabela 8 ).

6. As parcelas com vencimento entre os meses de janeiro e de novembro de 2015 foram pagas com atraso, em dezembro de 2015, o que gerou o pagamento de correção de $R \$ 450,57$ milhões do principal (Tabela 7).

7. As Portarias do Ministério da Fazenda que regulam os pagamentos no âmbito do Plano Safra não definem explicitamente o prazo para pagamento, mas o fazem de forma implícita, estipulando um marco temporal a partir do qual incidirá a correção da equalização devida.

8. Especificamente no que tange à Portaria $M F n^{\circ} 315 / 2014$, a atualização começava a ser acumulada a partir do primeiro dia após o final do prazo da equalização, sendo franqueados até vinte dias para que o Banco do Brasil apresentasse os documentos exigidos para a liquidação da despesa e para o consequente pagamento (art. $1^{\circ}$, \& $2^{\circ}$ da Lei $n^{\circ} 8.427 / 1992$, bem como arts. 62 e $63, \S 1^{\circ}$, ambos da Lei $n^{\circ}$ 4.320/1964). Nesse sentido, ante a inexistência de um termo para vencimento, vigorava o princípio da exigibilidade imediata da obrigação, devendo o pagamento ter sido efetuado na mesma data em que o Banco do Brasil apresentasse os referidos documentos.

9. A Portaria MF $n^{\circ} 419 / 2015$ autorizava o pagamento de equalizações geradas entre $1^{\circ}$ de julho de 2015 e 31 de dezembro de 2015. Caso o envio dos documentos ocorresse até o vigésimo dia do mês subsequente ao fim do período de apuração, haveria a verificação de conformidade, pela STN, até o último dia do mês. Caso isso acontecesse após esse vigésimo dia, o prazo de validação seria estendido até o último dia do mês subsequente ao do envio. A equalização seria corrigida após o primeiro dia do mês subsequente à validação de conformidade pela STN. Assim, o pagamento deveria ocorrer até o último dia do mês do envio dos documentos ou, se as informações fossem enviadas após esse vigésimo dia do mês, tal pagamento deveria ocorrer até o último dia do mês subsequente ao deste envio.

10. O pagamento da equalização relativa ao período de $1^{\circ}$ de julho a 31 de dezembro de 2015, conforme o art. $3^{\circ}$ da Portaria MF $n^{\circ}$ 915/2015, que revogou a Portaria no 419, deve ocorrer no prazo de cinco dias úteis, a contar do dia seguinte à data do recebimento dos documentos ou da reapresentação de suas versões corrigidas para validação. A correção da equalização devida ocorre, desde o último dia deste prazo para validação, até a data do efetivo pagamento. Dessa maneira, o pagamento deve ocorrer até o quinto dia útil da apresentação dos documentos que foram validados.

11. Os atrasos nos pagamentos devidos ao Banco do Brasil constituem operação de crédito, tendo a União como devedora, o que afronta ao disposto no art. 36 da LRF. Essa conclusão é extraída a partir do cotejamento entre a natureza desse passivo e os seguintes dispositivos, todos da LRF: art. 29, inciso III e $\S 1^{\circ}$; art. 35, caput. 
12. Pela análise dos dados, dos documentos e das informações relativos ao Plano Safra, não foi identificado ato comissivo da Exma. Sra. Presidente da República que tenha contribuído direta ou imediatamente para que ocorressem os atrasos nos pagamentos ${ }^{99}$.

\subsubsection{A sentença de impeachment da Sra. Dilma Rousseff}

Em acolhimento da acusação, o Senado Federal, em sentença assinada pelo Presidente da Sessão de julgamento, Ministro Ricardo Lewandowski (Ministro Presidente do Supremo Tribunal Federal), em 31 de agosto de 2016, assim decidiu:

O Senado Federal entendeu que a Senhora Presidente da República DILMA VANA ROUSSEFF cometeu os crimes de responsabilidade consistentes em contratar operações de crédito com instituição financeira controlada pela União e editar decretos de crédito suplementar sem autorização do Congresso Nacional previstos nos art. 85, inciso VI, e art. 167, inciso V, da Constituição Federal, bem como no art. 10, itens 4, 6 e 7, e art. 11, itens 2 e 3, da Lei n ${ }^{\circ} 1.079$, de 10 de abril de 1950, por 61 votos, havendo sido registrados 20 votos contrários e nenhuma abstenção, ficando assim a acusada condenada à perda do cargo de Presidente da República Federativa do Brasil ${ }^{100}$.

\section{7. $\quad$ APORTES CONCLUSIVOS}

Em conclusão à presente seção deste AC, entende-se que embora a OC não seja a melhor sede para resolver todas as questões que envolvam as minúcias procedimentais dos casos concretos submetidos à CIDH e, eventualmente, à Corte IDH, o presente AC buscou evidenciar formas pelas quais as garantias procedimentais previstas no SIDH podem servir como uma salvaguarda formal a um uso distorcido do impeachment. Nesse sentido, espera-se que esta Corte IDH busque interpretar os artigos $8^{\circ}, 9^{\circ}, 23$ e 25 da Convenção, com um olhar atento para a normatividade que decorre dos diálogos vertical e horizontal.

\section{A CENTRALIDADE DO ARTIGO 23 DA CADH SOBRE OS PROBLEMAS ATUAIS DA REGIÃO: A INSTRUMENTALIZAÇÃO DO CONTROLE DE CONVENCIONALIDADE PARA CONSOLIDAR O HIPERPRESIDENCIALISMO E A TENSÃO ENTRE DIREITOS POLÍTICOS E OS PODERES SANCIONATÓRIOS DAS AUTORIDADES PÚBLICAS}

Na primeira parte deste AC se sustentou que a Corte IDH não deve resolver a consulta solicitada pela CIDH ou, pelo menos, não deve fazê-lo sem antes explicar as razões que justificam a competência consultiva da Corte IDH, neste caso particular, à luz das próprias regras que o Tribunal fixou sobre o assunto. Além disso, nesse caso, observou-se que a Corte IDH deve reformular as perguntas elaboradas pela Comissão para distinguir esta consulta da que foi formulada (e inadmitida pela Corte IDH) previamente pelo Secretário-Geral da OEA. Na segunda parte, afirmou-se que a Corte IDH deve adotar um enfoque de deferência em relação aos Estados em áreas com forte conteúdo político. Na terceira parte, ofereceu-se um contexto dialógico para que a Corte Interamericana de Direitos

\footnotetext{
${ }^{99}$ Brasil, Senado Federal, Parecer da Junta Pericial designada no âmbito da Comissão Especial do Impeachment 2016, op. cit.

${ }^{100}$ Brasil. Senado Federal. Sentença. Disponível em: <https:/goo.gl/DE3sKK>.
} 
Humanos tenha elementos de julgamento nos casos em que decida resolver investigações formuladas pela CIDH.

Nessa mesma linha, este AC termina com uma advertência ao Tribunal Interamericano, sobre a necessidade de ampliar a interpretação do artigo 23 da CADH e corrigir as omissões, nas quais incorreu o Tribunal, a respeito desta importante disposição da $\mathrm{CADH}$, quando ele conheceu de casos contenciosos ${ }^{101}$.

Com efeito, a Corte IDH deve tomar nota da excessiva austeridade com a qual interpretou o artigo 23 da CADH. Do ponto de vista técnico, essa austeridade tem se manifestado, quando o Tribunal tem aplicado de maneira exclusiva o método originalista de interpretação, tanto na sua versão textualista como voluntarista, no enfrentamento de problemas que envolvem o artigo 23 da CADH.

Como observado em outro lugar, o originalismo aplicado à interpretação do artigo 23 da CADH não só contrasta com a aplicação do método de interpretação evolutiva que o Tribunal Interamericano tem propagado na hermenêutica da $\mathrm{CADH}$ e nos demais tratados de direitos humanos, como tem omitido aspectos importantes dos problemas que tem que resolver em relação ao artigo 23 da CADH. Para mencionar apenas alguns, a Corte IDH omitiu a posição dos direitos dos eleitores, da oposição ou das mulheres quando resolveu os casos contenciosos de direitos políticos ${ }^{102}$.

Além do exposto, a Corte IDH deve tomar nota de que a austeridade excessiva e o originalismo aplicado à interpretação do artigo 23 da CADH têm causado problemas e disfunções no interior dos Estados. Entre outros, os que se manifestam com mais força são o uso instrumental do artigo 23 da CADH e do controle de convencionalidade para provocar rupturas no princípio da separação de poderes, freios e contrapesos, na alternância no poder e na democracia constitucional, através da não aplicação de normas internas (legais ou constitucionais) que proíbem a reeleição de funcionários públicos.

Além disso, a descontextualizada e originalista interpretação do artigo 23 da CADH tem causado insegurança jurídica quanto às obrigações dos Estados para processar e punir a corrupção. Nesses casos, a interpretação estabelecida desde 2011 do artigo 23 da CADH ameaça esvaziar de poder as várias instituições nacionais responsáveis por punir funcionários públicos eleitos pelo voto popular quando do cometimento de atos de corrupção. Essa ameaça paira sobre essas instituições nacionais, mesmo quando elas aplicam satisfatoriamente as garantias judiciais do artigo $8^{\circ}$ da CADH e quando o acesso a um recurso judicial efetivo, nos termos do artigo 25 da Convenção, é garantido.

A interpretação originalista do artigo 23 da CADH tem como resultado o seguinte paradoxo em termos de diálogo judicial: os tribunais internos que tradicionalmente dialogam com a Corte IDH têm se apartado dos padrões interamericanos quanto ao artigo 23 da $\mathrm{CADH}$, em relação às funções disciplinares dos funcionários popularmente eleitos, enquanto os juízes nacionais que têm demonstrado maior resistência ao diálogo com a Corte Interamericana têm exercido o controle de convencionalidade e têm utilizado o artigo 23 da CADH como fundamento para não aplicar as normas nacionais que proíbem a reeleição presidencial.

\footnotetext{
101 Jorge Ernesto Roa Roa. "Las antinomias entre las Constituciones y la Convención Americana sobre Derechos Humanos: el gran dilema del juez constitucional y convencional interamericano”. En: Saiz Arnaiz, Alejandro (coord.); Solanes, Joan y Roa, Jorge (eds.). Diálogos judiciales en el Sistema Interamericano de Derechos Humanos. Tirant lo Blanch, Valencia, 2017, p. 137-162.

102 Jorge Ernesto Roa Roa, “Las antinomias entre las Constituciones y la Convención Americana”, op. cit., p. 137-162.
} 
O Tribunal não é exclusivamente responsável pelo uso inadequado, instrumental ou desviante da sua própria jurisprudência pelas autoridades nacionais. No entanto, ele é responsável pela interpretação adequada e completa dos tratados internacionais que definem sua competência ratione materia e pelo impacto interno que a aplicação de métodos de interpretação expirados tem sobre a hermenêutica constitucional e sobre a hermenêutica do direito internacional dos direitos humanos.

Todas as considerações formuladas previamente nesta peça de AC se fazem com o devido respeito ao Tribunal Interamericano e com a confiança na abertura deliberativa de quem quer que integre o Tribunal. Da mesma forma, todas as críticas formuladas nesta OC se fazem com base na confiança nos órgãos do SIDH e na firme convicção de sua potencial melhoria com base na contribuição construtiva dos Estados e da sociedade civil.

As autoras e autores desta peça manifestam à Corte IDH sua intenção de participar na audiência pública sobre o procedimento de OC.

À senhora juíza e aos senhores juízes da Corte Interamericana de Direitos Humanos, por

\section{Jorge Ernesto Roa Roa}

Docente e Investigador na Universidad Externado de Colombia

C.C. 1.032.389.547 (Colômbia)

Endereço: Cra. 13A No. 28-21. Apto. 2903. Bogotá D.C. (Colômbia)

Tel: (+57) 3192518296

Fax: (+57-1) 2839406

\section{Vera Karam de Chueiri}

Coordenadora do Núcleo Constitucionalismo e Democracia da Universidade Federal do Paraná

Endereço: Praça Santos Andrade, 50 - Centro, Curitiba - PR, 80020-300 (Brasil)

Tel: (+55 41) 3310-2688

(+55 41) 3310-2663 